
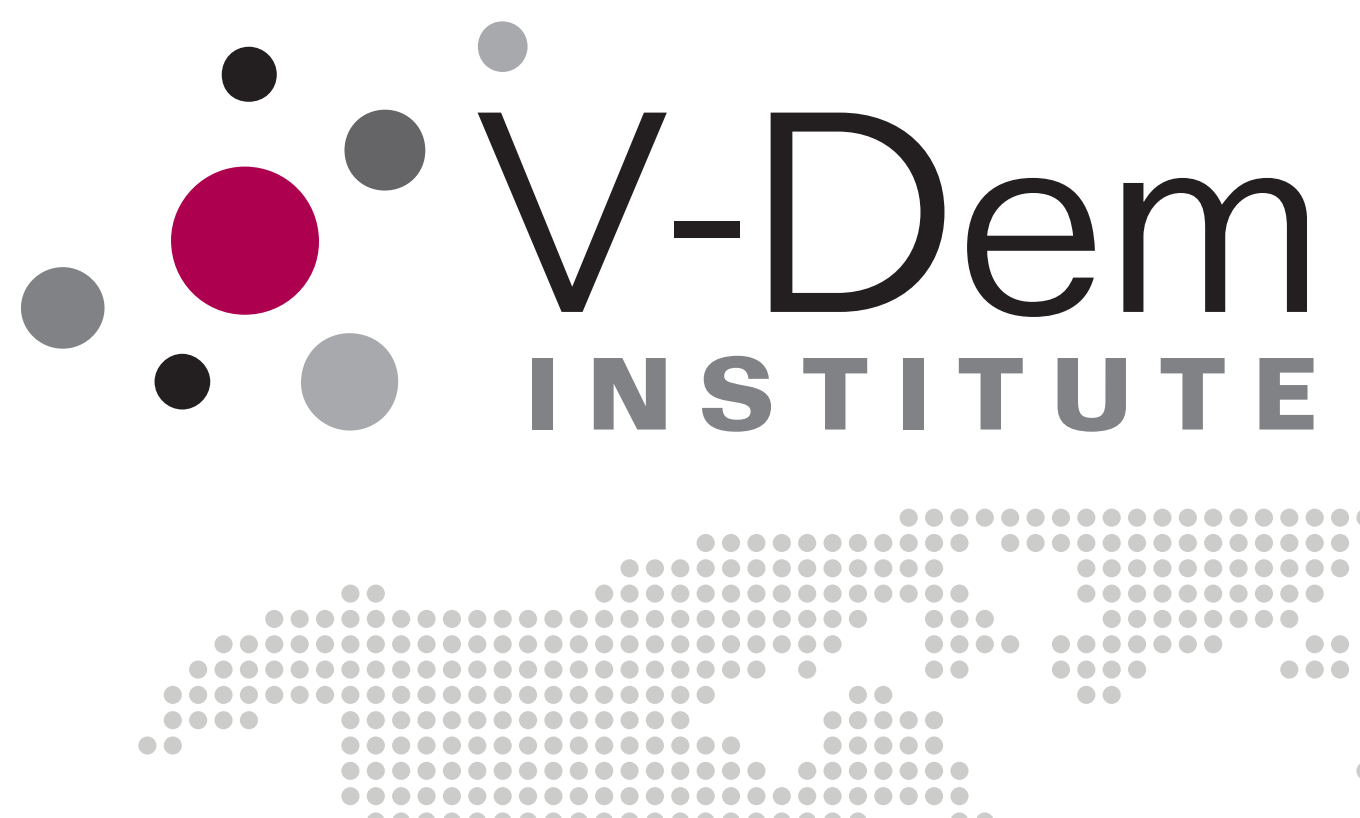

Environmental Commitments in Different Types of Democracies: The

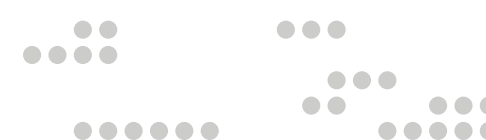
60080080 3000 

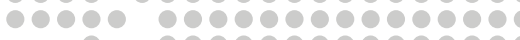
- 0000000000000

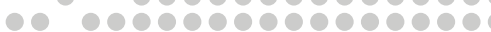

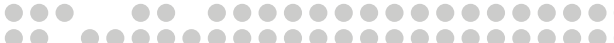
מصm 100000000000000000

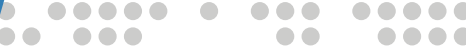
00000000000000

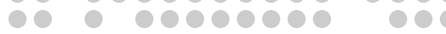
1

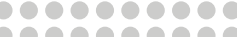
 1000000000000000000 ○०000000000 000000 Role of Liberal, Social-liberal, and Role of Liberal, Social-liberal, and Deliberative Politics

Marina Povitkina Sverker C. Jagers

00000000

1000000

000000

190900

10000

000

000

10

80

80 3000000000000000

00000000000000000 100000000000000000000 10000000000000000

-



o.

0000000000

0000000000

O00000000

○000000000е

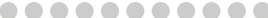

o0000000000

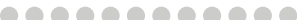

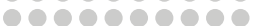

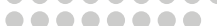

00000000

○००००००

100000

00000

1000

100

\author{
(n)
}

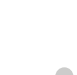

80

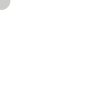

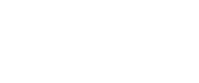

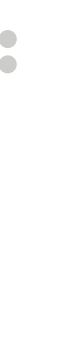


Varieties of Democracy (V-Dem) is a new approach to conceptualization and measurement of democracy. The headquarters - the V-Dem Institute - is based at the University of Gothenburg with 23 staff. The project includes a worldwide team with 5 Principal Investigators, 19 Project Managers, 33 Regional Managers, 134 Country Coordinators, Research Assistants, and 3,500 Country Experts. The V-Dem project is one of the largest ever social science research-oriented data collection programs.

Please address comments and/or queries for information to:

\author{
V-Dem Institute \\ Department of Political Science \\ University of Gothenburg \\ Sprängkullsgatan 19, Box 711 \\ 40530 Gothenburg \\ Sweden \\ E-mail: contact@,v-dem.net
}

V-Dem Working Papers are available in electronic format at www.v-dem.net.

Copyright (C2021 by authors. All rights reserved. 


\title{
Environmental commitments in different types of democracies: The role of liberal, social-liberal, and deliberative politics
}

\author{
Marina Povitkina \\ University of Oslo \\ Sverker C. Jagers \\ University of Gothenburg
}

*The authors are grateful to Environmental Politics and Governance group, John Hoornbeek and other participants at the 'Institutions, Trust, and Social Dilemmas' panel of the Midwest Political Science Association Conference 2018, Andreas Duit, Sijeong Lim, and other participants at the Environmental Politics and Governance conference 2018, Bård Harstad, Katinka Holtsmark and other participants of the 'The Politics and Economics of Environmental Policy' workshop 2019 at the University of Oslo, researchers at the Comparative Institutions and Regimes group at the University of Oslo, and researchers at the Center for Collective Action Research at the University of Gothenburg or useful comments and suggestions. This research project was supported by the Center for Collective Action Research, University of Gothenburg, Sweden. 


\begin{abstract}
Ever since the recognition of ongoing, human-induced, large-scale environmental degradation, from the early 1960s onwards, the scholarly community has looked at democracy with mixed feelings. Some assert, quite openly, that democracy is devastating for the environmental performance of countries, some claim the opposite, while yet other scholars suggest that democratic models other than liberal democracy may offer a route forwards, towards a sustainable society. Both political theorists and empirical social scientists add fuel to this debate, and neither side has of yet settled the argument. For obvious reasons, political theorists typically lack empirical evidence for most of their assertions as to whether democracy per se, or different variants of democracy, are more or less pro-environmental. In parallel, empirically oriented scholarship has been impaired with poor data, often obstructing them from properly evaluating democracy's actual environmental pros and cons. In this paper we make use of recently collected unique data, enabling us to better address both these literatures. Using the data gathered by the Varieties of Democracy project on different conceptions of democracy, we empirically test whether different features of democracy, such as liberal in its thinner understanding, socialliberal, and deliberative, are beneficial for countries' commitment to environmental improvements. In particular, we investigate which of these distinct features make democracies more prone to deliver environmental policy outputs, i.e., adopt climate laws, develop stricter environmental policies and incorporate sustainability into economic policies.
\end{abstract}

Keywords: democracy, autocracy, environmental commitments, liberal, social-liberal, deliberative. 


\section{Introduction}

Which political system is best suited to deal with problems related to the environment and, by extension, to contribute to global sustainable development? Even if some environmental problems may have been solved, mitigated or, alternatively, been exported to parts of the world where mainly developed countries do not experience them anymore, this question remains focal. Despite a rather short history of public and political attention - basically only some fifty to sixty years - environmental problems have already taken on many different guises, and every one of them is, indeed, politically challenging. In the 1960s, environmental problems primarily referred to rather isolated issues, such as emissions and pollution. Gradually, focus on the environment increasingly became a matter of global sustainable development, including an emphasis on both pure environmental status and economic and social development, where the principal actors and agents of moral interest and concern, exist both today and in a distant future. ${ }^{1}$ As we see it, the more complex and all-embracing environmental issues become, the more justified it is to simultaneously ask which political system is best armed to deal with environmental problems?

One, currently rather popular, response is to argue that preventing and coping with an approaching environmental system collapse requires some kind of 'Earth System Governance' arrangement (Biermann, 2014; Burch et al., 2019) albeit without really specifying what type of political system this would presuppose (democracy or some other form of government), nor what steering mechanisms such a governance system would be constituted by. Another popular approach over the years is to simply conclude that since most environmental problems have been generated in democratic countries, democracy needs to be exchanged for some other form of government if we are ever to overcome environmental problems (Ehrlich, 2013; Heilbroner, 1974; Kennedy, 1993; Ophuls, 1977). This line of argument has gained some additional fuel lately as investment in green technology has rapidly expanded in China, according to some observers, supposedly indicating that authoritarian regimes are better equipped to deal with environmental challenges (see Randers, 2012).

We see few advantages in trying to approach our research problem along any of these two routes. The first endeavour appears to indicate some kind of social science fiction version of state theory, steering us away from any ambitions to concretely contribute to the understanding

\footnotetext{
${ }^{1}$ In later years, scientists and policy makers have instead begun to talk about the Anthropocene, referring to an already ongoing geological era during which humanity is the principal driver of the changes we see on the globe today and where the environment is understood as an extremely complex 'Earth system', defined by planetary boundaries and currently dashing towards collapse at a rapidly increasing speed.
} 
of prospects for successful environmental politics, while the second falls short on a number of premises, including the empirical fact that other than China and Singapore, authoritarian regimes have generally not paid active attention to environmental problems. ${ }^{2}$

Instead, we aim to investigate the question as to which political system is best suited to deal with environmental issues from two other angles. First, in the field of green political theory there is a mature and well-elaborated debate concerning which political system is best equipped to cope with environmental problems. ${ }^{3}$ At least one common denominator within this by now rather dated literature is that democracy is not necessarily bad for the environment as such, but rather that the liberal-democratic model in particular is the major root for most of the environmental challenges that we are confronted with today. One reason for this is an assumed close relationship between liberal democracy and negative political rights on the one hand and capitalism/the market on the other, both of which can be devastating for the environmental cause (and, for that matter, also for any ambitions to upgrade moral concern and responsibility such that future generations' interests are included into present-day decision-making). Therefore, alternative models have been suggested, and these are primarily i) social-liberal democracy and ii) deliberative democracy. A problem with this theoretically founded literature is, however, that it has seldom, if ever, been subject to empirical scrutiny. Thus, apart from a few examples of case studies investigating whether the practicing of alternative democracy models would be more beneficial for the environment (Bäckstrand, Khan, Kronsell, \& Lövbrand, 2010; Dryzek, 2001, 2011), it remains an open question as to whether this is actually the case or not.

A second strand of literature is much less theoretically informed, and instead focuses on studying whether democratic countries are generally better equipped to generate environmental solutions compared to authoritarian regimes (Bättig \& Bernauer, 2009; Li \& Reuveny, 2006). The latter approach can, and has been, criticized for not distinguishing between different types of

\footnotetext{
2 According to Paehlke (1995, p. 140) the authoritarian solution can be criticised from at least the following three angles: 1) authoritarian rulers are unlikely to be sensitive to, or informed about ecological matters; 2) authoritarian regimes are not necessarily good at inducing positive behaviour, especially in the long term; 3) democracy provides a much better climate for social and economic mobilisation. Paehlke's notes can be elaborated somewhat further. First, there is no empirical support for an authoritarian regime's success in solving environmental problems, while environmental improvements have been fairly significant in many democracies. Second (which is a matter that can be related to the issue of political decision permanency), even if an eco-authoritarian political regime was to be established, there are no guarantees that the eco-focus will be kept over time. What will happen the day the ecological king dies? See also Barry (2014, pp. 194-202) for a short but illuminating critique of the idea of an authoritarian political system, and Lafferty \& Meadowcroft (1996, p. 3) on whether authoritarian political systems have been proved more eco-efficient than democratic ones. Ostrom (1990) discusses self-organizing environmental management as an empirical (and theoretical) response to the tragedy-paradigm. See also Radcliffe's (2000) examination of Ophuls (1977) and Heilbronner (1974).

${ }^{3}$ In fact, it appears to be so well elaborated that the debate has almost vanished in latter years.
} 
democratic models or regimes. A likely reason for this empirical gap has been the lack of available data.

In this paper, we amalgamate these two approaches and empirically test if countries that are drawn towards 'thin' liberal-, social-liberal, or deliberative democracy are more successful in developing environmental commitments compared to countries drawn towards other types of democratic regimes. We are thus not trying to attribute a country to a certain political system, but we rather try to categorize countries as having more or less of these three features in their respective political constructs.

Our measures of different features of democracy are founded on data from the Varieties of Democracy Project and the Index of Economic Freedom from the Fraser Institute (2020), while data on environmental commitments is from Eskander and Frankhauser (2020), OECD statistics (Botta \& Koźluk, 2014), and the expert survey for the Transformation Index from Bertelsmann Stiftung (Donner, Hartmann, \& Schwarz, 2020).

Our analysis contributes to an 'evaluation' of the more than fifty-year-old academic debate concerned with determining which political system is best suited to cope with environmental problems. Our analysis also provides grounds for further theorizing on how future societies can successfully deal with the grand challenges associated with sustainable development and, even more so, with how to govern the Earth's ecosystems. In our view, to avoid drifting towards 'social science fiction', it is better to recognize and proceed from prevailing political systems and to discuss how they can be designed differently. To quote Eckersley (2004, p. 5): '...like it or not, those concerned about ecological destruction must contend with existing institutions and, where possible, seek to "rebuild the ship while still at sea"'.

In the next section, we first account further for the debate on the relationship between different democratic models and the environment. Further, we describe our empirical strategy, including operationalisation of our concepts, and present the regression equations underlying our statistical analyses. Thereafter, we present our results, followed by a discussion and a concluding section in which we critically examine our endeavours and discuss how this strand of research can be further advanced.

\section{Theory and previous research}

The ultimate goal of most current environmental policies is sustainable development, a global political project to fulfill human needs without jeopardising the ability of future generations to 
fulfill their own needs (World Commission on Environment and Development, 1987). For this to be realized, according to one of the instigators, The Brundtland Commission, 'painful choices have to be made' (World Commission on Environment and Development, 1987, p. 9). It is easy to agree with this. Reaching sustainable development goals is an arduous task for any political system. The question is simply - is it equally difficult for all political systems, or are some better equipped to secure strong environmental commitments than others?

\section{The flouted (thin) liberal democracy}

Over the years, many social theorists have argued that implementation of pro-environmental policies would be particularly difficult for/in liberal democracies, typically claiming that there are certain 'inherent weaknesses' of liberal democracy (De Geus, 2001, p. 20 ff) and thus that the whole foundation of liberal democracy is incompatible with environmental concerns (cf. Dobson, 2007, p. 164 ff).

Some assert that to claim a strong concern for environmental issues would violate the whole foundation of liberal democracy, that is autonomy and individual self-rule (Mathews, 1995, p. 69). This emphasis on individual freedom and autonomy works against the emergence of ecological identity and consciousness (1995, p. 94). Another critique concerns limits to the problem-solving capacity of liberal democracy. For example, the distribution of power in liberal democratic systems is inevitably skewed, and business always has a 'privileged' position due to the financial resources available to it (Dryzek, 1992, p. 22 ff). Liberal democracies also identify and disaggregate environmental problems based on the particular interests of affected parties. The time horizon in a liberal democracy is often no longer than that of the market. ${ }^{4}$ Furthermore, liberal democracy is addicted to economic growth because if growth ceases, then distributional inequalities become more apparent. This fear of economic downturn means that liberal democracies are 'imprisoned by the market's growth imperative' (cf. Hayward, 1998, p. 162).

As we can see, many of the theorists opposing liberal democracy's environmental credentials describe it as a very restricted form of democracy. It represents a compromise between liberalism's primary concern with individualistically conceived political and property rights on the one hand, and a vision of democratic representation, participation and accountability on the other (Barns, 1995, p.

\footnotetext{
${ }^{4}$ Eckersley (1995) agrees with Dryzek on liberal democracy's narrow time frames. 'Liberal democracies generally operate on the basis of very short time horizons (corresponding, at the most, with election periods)'. Furthermore, she claims that existing 'liberal democratic bargaining processes also deal very poorly with uncertainties and complexities of ecological problems' (Eckersley, 1995, p. 170).
} 
120). Such interpretations of 'liberal' prevent the state from interfering into individual liberties and regulating behaviour towards environmentally friendly standards.

We would like to note that the theories and theorists criticizing liberal democracies rarely, if ever, discuss liberal features pertaining to the rule of law and constraints on the executive that are beneficial for securing environmental commitments on the political agenda (cf. Povitkina \& Bolkvadze, 2019). Instead, they focus on a very thin understanding of liberal democracy and hypothesize that liberal democracy, as founded on this thin understanding of liberalism, should be a very poor political system when it comes to overcoming large-scale environmental challenges, be they generated in the past or still to come.

\section{Social-liberal democracy}

A response to the rather aggressive critique of thin liberal democracy is built on a thicker understanding of liberal democracy, that is, social- or developmental liberal democracy (Held, 1997), initially pronounced by (non-environmentally oriented) political theorists such as Rawls (1972), Dworkin (1981), Raz (1989), Sen (1988, 1992) and Rothstein (1999). There are at least three lines of argumentations that can substantiate such a claim (cf. Achterberg, 1993; Jagers, 2007).

First, a thicker, social-liberal understanding of liberal (democracy) allows for the inclusion of both negative and positive liberties and rights. In this way, it (at least theoretically) opens up the possibility that a healthy environment can be regarded as a positive and substantial right. Such a right is hardly plausible in a thin understanding of liberal democracy, as that would immediately be seen as a violation of more fundamental negative liberties and rights, such as the right to hold private property. Thus, it is conceivable that social-liberal democracies are more likely to protect the environment than thinner and more protective liberal democracies. The stronger the legal status such a positive environmental right has in a country, the more vigorously the government can act to the benefit of the environment, since what is at stake is actually the guarantee of citizens' equal rights to a healthy environment (cf. Gleditsch \& Sverdrup, 2003).

Second, the environment is commonly associated with development (cf. Sustainable Development). This often implies that unless countries and their citizens are enjoying a certain level of general social and economic wealth, there is a pronounced risk that the environment will be damaged due to factors such as lack of investment in efficient production and consumption and the risk that retained poverty will drive environmental degradation. If this is correct, then it 
is likely that the more developed, socially and economically, and social-liberal a country is, the better it will perform well in regard to the environment.

Third, there are also a number of, somewhat more political-philosophical, reasons to assume that governments in countries in which the ideological and political-cultural orientation is guided by more social-liberal principles could be expected to have more 'space' to act to the benefit of the environment. Most notable is the possibility to extend several classic principles asserted by a number of renowned (more or less) social-liberal theorists (cf. Jagers 2007), such as Mill's (1884) no-barm principle, Raz's (1989) generous understanding of state-neutrality, Sen's (1992) equality of capabilities, Dworkin's (1981) principle of equal concern and respect and Gewirth's (1978) autonomy principle.

While there are several arguments that can be used to substantiate the claim that social-liberal democracy should be more successful in generating pro-environmental politics, including the above-mentioned principles and the fact that a healthy environment can be considered a human right, it is important to emphasize that any such environmental inclusion and extension is in such a case achieved at the price of a more or less comprehensive reduction in the protection of other liberties and rights, especially the right to hold property. Thus, a green social-liberal democracy is most likely to be encumbered with higher income and wealth taxes but also be more ambitious in 'pushing' environmental policy instruments, such as various environmental taxes.

\section{Deliberative democracy}

Rather than thin understandings of liberal democracy, green democratic theorists have also commonly suggested varying forms of de-centralised democracy, sometimes called 'strong' democracy (Eckersley, 1995, p. 171). The most popular variant of strong democracy discussed among greens is 'deliberative' democracy (Barry, 2014; De-Shalit, 2000; Dryzek, 1987, 1990; Eckersley, 1997; Hayward, 1998; Jacobs, 1996). Such democracy refers to a form of collective decision-making that stresses the community over the market or the state as the location for first-order decisions concerning social-environmental relations.

This means that such a democracy makes the state and the market the instruments of the democratic decisions of the community. That is, the deliberative 'speech situation' reduces former power relations in such a way that each and every interest now speaks and argues on an equal footing, that is the best argument wins, no matter whose argument it is. Some even claim that in situations in which the good arguments outdo the bad ones, individuals' opinions can be changed in such a way that different opinions are not only modified, but also rectified, i.e., a 
former controversy ends up in 'consensus' (cf. Hayward 1998; Habermas 1996, p.100; Cohen 1997:75). As deliberative democratic institutions offer opportunities for broader public participation for a diverse set of actors, as well as setting a platform for deeper and more enlighted public debate, deliberative democracy is argued to benefit environmental commitments significantly more than the thin liberal variant (Smith, 2003).

In Table 1, we summarize the main features of the different ideal types of democracy, starting with the baseline democracy model, which is simply the thinnest possible procedural democracy, here termed electoral democracy.

Table 1. Four conceptions of democracy

\begin{tabular}{ll}
\hline Political system & Main features \\
\hline Baseline: Electoral Democracy & Thin procedural democracy (Dahl, 1971): \\
& elected officials \\
& free and fair elections \\
& universal suffrage \\
& freedom of expression/media \\
& freedom of association \\
\hline 'Thin' liberal democracy & Thin procedural democracy; strong individual liberties \\
& and strong markets \\
\hline Social-liberal democracy & Thin procedural democracy; levelled out inequalities, \\
& including economic inequalities and social inequalities \\
\hline Deliberative democracy & Thin procedural democracy; influence from social \\
& movements and citizens through public deliberation
\end{tabular}

\section{Empirical research on democracy and environmental performance}

Previous empirical research investigating whether or not democracy is beneficial for the environment has shown mixed results. The existing literature predominantly assesses the performance of democratic regimes comparative to authoritarian states in different types of environmental outcomes, such as the level of air emissions $\left(\mathrm{CO}_{2}, \mathrm{SO}_{2}, \mathrm{NO}_{\mathbf{x}}\right.$, etc.), water pollution (BOD, COD, lead, nitrates, etc.), deforestation, soil erosion, protection of natural resources, health of marine ecosystems, as well as commitment to international environmental agreements (Arvin \& Lew, 2011; Barrett \& Graddy, 2000; Bättig \& Bernauer, 2009; Bernauer \& Koubi, 2009; Fredriksson \& Wollscheid, 2007; Li \& Reuveny, 2006; Neumayer, 2002; Povitkina, 2018; Sjöstedt \& Jagers, 2014; Spilker, 2013). Most scholars find that higher democracy, as a general rule, is associated with stronger environmental performance. However, comparing the 
results between such studies and the different indicators of environmental performance reveals some inconsistency. One of the key shortcomings of the previous empirical scholarship on the democracy-environment nexus is that the relationship between democracy and environmental outcomes appears far-fetched, simply because there are many other important factors, originating from outside the political sphere, influencing these outcomes. In our view, it is thus more relevant to study what political regimes actually do to protect the environment - that is, adopt legislation or employ various policy instruments - rather than trying to capture potential outcomes of these political actions, such as the level of emissions.

Another important shortcoming of this scholarship is the lack of empirical accounting for the prescriptions elaborated by social theorists. While such theory predicts that democratic institutions can have different consequences for countries' environmental performance, primarily depending on the ideological and other political-ethical ideals (i.e., ideals influenced by thin liberal-, social-liberal- and deliberative theory) dominating in the different democracies, to our knowledge there have been no empirical studies that actually distinguish between the effects of such different ideological and other political-ethical ideals on the environment. In this paper, we aim to fill both these gaps by investigating how countries that are empirically leaning towards different ideal types of democracy actually perform in terms of their environmental commitments. Our study is explorative and, therefore, we do not derive any hypotheses from the theoretical literature, but we rather remain open to the patterns we discover during the empirical investigation.

\section{Econometrics and operationalization}

\section{Data}

\section{Environmental commitments}

We measure the extent of countries' commitment to combat environmental problems through several indicators. First, we replicate the findings by Eskander and Fankhauser (2020), in which the authors estimate reductions in carbon dioxide emissions from national climate change mitigation legislation. We subsequently add our democracy indicators into their models as moderators, with the intention of examining which democracies, with which dominating features, have succeeded in reducing $\mathrm{CO}_{2}$ emissions after introducing climate change legislation. The dependent variable is $\mathrm{CO}_{2}$ emission intensity measured in mega tons of $\mathrm{CO}_{2}$ per unit of economic output (2011 PPP \$1 GDP), log-transformed. The data on climate laws and policies in Eskander and Fankhauser (2020) comes from the Climate Change Laws of the World dataset 
from the Grantham Research Institute on Climate Change and the Environment in the London School of Economics (2020). The dataset contains information on all climate-related documents adopted by countries' governments up until 2020. The published article analyses the laws up to 2016 and uses a variable measuring 'stock of recent climate change mitigation laws', a rolling sum of adopted laws over 3 year-periods.

Second, we use an indicator from the OECD database on the stringency of environmental policies. The index is a composite measure that aggregates market-based and non-market-based policy instruments. These policy instruments include environmental taxes on $\mathrm{SO}_{\mathrm{x}}, \mathrm{NO}_{\mathrm{x}}$, diesel, and $\mathrm{CO}_{2}$; trading schemes in $\mathrm{CO}_{2}$; renewable energy and energy efficiency certificates; feed-in tariffs on solar and wind energy; deposit and refund schemes; emission limit values on $\mathrm{NO}_{\mathrm{x}}, \mathrm{SO}_{\mathrm{x}}$, $\mathrm{PM}_{\mathrm{x}}$ and sulphur content limits in diesel, as well as government expenditure on research and development within renewable energy (Botta \& Koźluk, 2014). Higher scores on the index correspond to higher environmental policy stringency. The indicator is available for 34 countries in the OECD and BRIICS 5 between 1990-2015, with gaps, but for most countries the coverage only extends until 2012.

Third, to explore the variation in the non-OECD countries, we take an 'Environmental Policy' indicator from the Bertelsmann Stiftung's Transformation Index (Donner et al., 2020). The indicator is an expert evaluation of the extent to which 'environmental concerns [are] effectively taken into account' in macro- and microeconomic terms, per country per year. The indicator ranges from 1, 'Environmental concerns receive no consideration and are entirely subordinated to growth efforts. There is no environmental regulation', to 10, 'Environmental concerns are effectively taken into account and are carefully balanced with growth efforts. Environmental regulation and incentives are in place and enforced'. For example, 4 on the scale means 'Environmental concerns receive only sporadic consideration and are often subordinated to growth efforts. Environmental regulation is weak and hardly enforced' and 7 means 'Environmental concerns are taken into account but are occasionally subordinated to growth efforts. Environmental regulation and incentives are in place, but their enforcement at times is deficient'. The indicator thus captures countries' environmental commitment. For more information about the methodology of indicator construction see Donner et. al. (2020). The indicator covers 137 developing countries between 2006 and 2020, with a gap every second year.

\footnotetext{
${ }^{5}$ Brazil, Russia, India, Indonesia, China, and South Africa.
} 


\section{Conceptions of democracy}

We cannot strictly categorize existing democracies into the different 'ideal' democracy types, as most countries have only developed aspects related to the democratic ideal types to a certain degree. For example, social-liberal democracies might also have some elements of the thin liberal features while at the same time enjoying, to a certain extent, the processes associated with deliberation. This means that it is not possible to empirically categorize countries into clear 'types' - they will all possess traces of all three models. We therefore instead measure the degree to which the 'thin' liberal, social-liberal and deliberative features are developed in countries, and our country rankings reflect the prevalence of certain features over others.

We measure different democratic features using data from the Varieties of Democracy Project (V-Dem) on different conceptions of democracy (Coppedge, Gerring, Knutsen, Lindberg, Teorell, Altman, Bernhard, Fish, Glynn, Hicken, Lührmann, Marquardt, McMann, Paxton, Pemstein, Seim, Sigman, Skaaning, Staton, Wilson, et al., 2020) and the Fraser Institute's Index of Economic Freedom (2020). While the V-Dem project suggests its own indicators of liberal, social-liberal (egalitarian), and deliberative features for capturing different types of democracy (Lindberg, Coppedge, Gerring, \& Teorell, 2014), indicators measuring these features are highly correlated $(>0.7$, see Appendix F) and therefore hard to distinguish from one another in the correlational analysis. Moreover, the indicator measuring liberal features from V-Dem does not capture the strength of the market, which is emphasized as an important deterrent of environmental commitments in green political theory. For these reasons, we construct our own indices of democratic features. We still use the measurement model output for expert answers to individual survey questions from V-Dem to measure deliberative and social-liberal (egalitarian) features (Pemstein et al., 2020), but we only select the key questions to capture the theoretical arguments raised in the environmental politics literature, to minimize correlation between our indices. ${ }^{6}$ In order to measure thin liberal features, we only use the components of the Fraser Institute's Index of Economic Freedom.

In our baseline model, we use the Electoral Democracy Index as an indicator of a thin procedural democracy. The index is based on the conceptualization of democracy as polyarchy developed by Dahl (1971). The index includes measures of the degree to which elections are free and fair, whether suffrage is universal, whether citizens are free to express their opinions and organize in civil society organizations and political parties, and whether officials are elected

\footnotetext{
${ }^{6}$ We nevertheless perform the analysis using V-Dem indicators as a robustness check, see Appendix F.
} 
through popular elections. The index ranges from 0 to 1 , where higher values indicate more developed electoral democracy principles.

According to existing theories, the main critique of liberal democracy in its thin conception lies in the relative strength of the market and the influence of business in political decision-making, as well as a commitment to strong individual liberties that prevents governments from enforcing environmentally friendly behaviour on their citizens. We gauge the presence of these features using indicators from the Index of Economic Freedom from the Fraser Institute (Fraser Institute, 2020). We opted for using as many indicators that tap into individual and business freedom from government regulation as possible. The indicators we included are: the size of government, protection of property rights, freedom to own foreign currency bank accounts, tariffs on foreign trade, controls on the flow of capital, and credit market regulations. We do not integrate indicators related to regulatory quality, rule of law and ease of doing business as they tap into features of political systems other than thin liberal ones and are further away from the aspects discussed in green political theory that we are aiming to capture. ${ }^{7}$ For this reason, the survey questions included in the measurement of liberal democracy from V-Dem are less useful for out tests, as they measure individual freedoms and constraints on the executive. For more information on the indicators see Appendix A.

To capture social-liberal features of countries, we use indicators that reflect inequalities within countries, including inequalities resulting in unequal access to healthcare (v2pehealth) and education (v2peedueq), whether policies are universalistic or means-tested (v2dlunivl), and whether expenditures go towards particularistic or public goods (v2dlencmps). The indicators that we code into our social-liberal features can thus help us test if societies that strive for universal welfare also have higher environmental commitments.

We measure democracies' deliberative features using questions from the V-Dem dataset that gauge how wide and independent public deliberations are (v2dlengage), whether the political elites acknowledge and respect counterarguments when making policy revisions (v2dlcountr), whether policymakers consult civil society organizations (v2cscnsult) and whether the range of consultation is wide enough to include the entire political elite and 'all politically relevant sectors

\footnotetext{
7 The concept of liberal democracy in political science usually extends beyond strong individual liberties to include the degree of rule of law and constraints on the executive. The role of these important aspects of liberal democracies in countries' environmental commitments is rarely discussed in green political theory. Instead, scholars mostly focused on the constraints described in our theory section. As our goal is to test the arguments brought up in green political theory, in this paper we only cover the aspects of liberal democracy relevant to these arguments. We put the label 'thin liberal' to the set of components that we investigate for convenience, so as to speak to these arguments, and do not aim to redefine the concept 'liberal' as established in the political science literature.
} 
of society and business' (v2dlconslt). The indicators of deliberative features thus capture the extent of deliberation and consultation with relevant actors.

We calculate the indices of thin liberal, social-liberal and deliberative features by conducting a series of factor analyses, extracting the factor scores using maximum likelihood estimation (mlmv in STATA). After factor analysis, the thin liberal, social-liberal, and deliberative indices are standardized and are therefore on the same scale, which makes it convenient for effect comparison. We rescale the indices to take only positive values. ${ }^{8}$

Table 2 summarizes our strategy for the operationalization of different features of democracies.

To ensure that we measure the features of democracy we only perform our analysis on the sample of democracies in our main analysis. We divide democratic and authoritarian regimes using the dichotomous democracy index from Bjørnskov and Rode (2020), which is an extended version of the democracy index from Cheibub, Gandhi and Vreeland (2010).

Table 2. Strategy for operationalization of different features of democracies

\begin{tabular}{ll}
\hline Features of democracy & Operationalization \\
\hline Electoral democracy (Model 1) & Electoral democracy index (v2x_polyarchy, V-Dem) \\
\hline Thin liberal features (Model 2) & Size of government; \\
& Protection of property rights; \\
& Freedom to own foreign currency bank accounts; \\
& Tariffs on foreign trade; \\
& Capital controls; \\
& Credit market regulations \\
\hline Social-liberal features (Model 3) & Equality in access to healthcare; \\
& Equality in access to education; \\
& Spending on particularistic or public goods; \\
& Means-tested or universalistic policy \\
\hline Deliberative features (Model 4) & Extent of public deliberations; \\
& Officials' respect for counterarguments; \\
& Extent of civil society consultation; \\
& Range of consultations \\
\hline
\end{tabular}

We make sure to control for other relevant factors that impact environmental commitments in democracies. First, we take into account countries' levels of economic development and include

\footnotetext{
${ }^{8}$ This is to prepare them for the calculation of indices of different democracy features for the additional analysis we perform in Appendix D.
} 
a value of countries' GDP per capita from the World Bank Development Indicators (2016), available through the Quality of Government Institute (Teorell et al., 2020). Higher income is often associated with higher likelihood that people have developed post-materialistic values and demand environmental policies (Inglehart \& Welzel, 2005). Countries that have been members of the European Union have been pressured to adopt certain environmental policies, and therefore we control for the amount of time a country has been a member of the EU. To account for the impact of international trade and economic globalisation on the adoption of environmental policies, we include the measure of countries' involvement in trade from the World Bank Development Indicators (2016). We additionally include the measure of political corruption from the Varieties of Democracy Dataset (Coppedge, Gerring, Knutsen, Lindberg, Teorell, Altman, Bernhard, Fish, Glynn, Hicken, Lührmann, Marquardt, McMann, Paxton, Pemstein, Seim, Sigman, Skaaning, Staton, Wilson, et al., 2020), which is detrimental to the strength of environmental commitments.

In the models that we replicate from Eskander and Fankhauser (2020), we use their set of independent variables, which includes a squared term of GDP per capita, import share as a percentage of GDP, services share as a percentage of GDP, deviation from average air temperature, a cyclical component of GDP based on a Hodrick-Prescott (HP) decomposition, and a dummy for whether a country uses a federal system. For the list of sources and methodology, see Eskander and Fankhauser (2020).

\section{Model}

In this exploratory analysis, we are interested in estimating if there are substantial differences in environmental commitments between countries depending on the features of which ideal democratic type are more pronounced, but also whether developments in any of the features within democracies over time has any association with the change in their environmental commitments. We therefore, utilize time-series data whenever possible. When we replicate the model by Eskander and Fankhauser (2020), we estimate the following equation:

$$
y_{i t}=\beta_{0}+\beta_{1} S_{i t}^{s}+\beta_{2} \text { demtype }+\beta_{3} S_{i t}^{s} * \text { demtype }+\beta_{3} z_{i t}+\theta_{i}+v_{t}+e_{i t}
$$

where $y_{i t}$ represents the $\log$ of $\mathrm{CO}_{2}$ emission intensity in country $i$ at year $t$, that is, $y_{i t} \equiv$ $\ln \left(\frac{E_{i t}}{G D P_{i t}}\right) . S_{i t}^{S} \equiv \sum_{k=1}^{3} L_{i(t-k)}$ is the stock of laws passed in the previous three years, which measures the short-term effect of legislation. Vector $z_{i t}$ is a set of control variables, described above. $\theta_{i}$ is country fixed effects and $v_{t}$ is year fixed effects, $\varepsilon_{i t}$ is an error term. The country 
effect controls for time-invariant factors such as different political cultures. The time fixed effect controls for intertemporal trends common across countries, such as knowledge and salience of climate change and fall in renewable energy costs.

When examining the relationship between the different features of democracy and the environmental policy stringency index among OECD countries and the environmental sustainability efforts among developing countries, we estimate using the within-between model suggested by Bell and Jones (2015). The within-between model recognises the hierarchical structure of the data and simultaneously accounts for variation between the countries and developments over time within states. The model allows for the use of random effects by addressing the issue of correlated errors between the two levels of estimation (cross country and over time) through mean centring of time-varying variables and simultaneous inclusion of their country means. Following the Bell and Jones (2015) guidelines, we calculate deviations from the country means for each independent variable and use them instead of the raw values together with the country means. The model can be summarized in the following equation:

$$
y_{i t}=\beta_{0}+\beta_{1}\left(x_{i t}-\overline{x_{l}}\right)+\beta_{2} \overline{x_{t t}}+\beta_{3} z_{i}+\left(u_{i}+e_{i t}\right)
$$

where $i$ stands for country, and $t$ - for year; $\beta_{0}$ is an intercept, $x$ is a vector of independent timevarying variables, while $z$ is a vector of time-invariant variables; $u$ is an error of the between equation, while $e$ is an error in the within-equation.

We estimate the equations several times. First, we conduct the analysis for the sample of democracies only, to explore how thin liberal, social-liberal, and deliberative features correlate with environmental commitments, specifically among democratic states. Second, we conduct the analysis for the sample of all countries, with thin liberal, social-liberal and deliberative democracies included as predictors and authoritarian regimes coded as 0 in these indexes of democracy (in Appendix D). This allows us to compare how the different democracy types perform in relation to authoritarian regimes. Third, we conduct the analysis for the sample of all countries without distinguishing between regime types to investigate whether the theorized features are important in predicting the performance of non-democratic regimes (in Appendix E). We compare the performance of different democracy types by comparing the size of their coefficients, as they are on the same scale, whether the coefficients are statistically significant, as well as the statistics on how well the models explain the variance in the dependent variable $\left(R^{2}\right)$. 


\section{Results}

The results of our model estimations with different dependent variables are presented in Tables Table Error! Reference source not found.. Table summarizes the results from the replication of Eskander and Fankhauser (2020), a country-year fixed-effects estimation of the effect of the number of climate laws on $\mathrm{CO}_{2}$ emissions. We added an interaction term between 'the stock of laws for the latest three years' and the different features of democracy to estimate the effect of the number of laws on $\mathrm{CO}_{2}$ emissions, depending on the prevalent democratic feature. Model 1 presents the results for the interaction effect between the electoral democracy index and the number of laws, Model 2 presents the results for the interaction effect between thin liberal features and the number of laws, Model 3 - the interaction effect between social-liberal features and the number of laws and Model 4 - the interaction effect between deliberative features and the number of laws.

The results are statistically significant for the models with thin liberal and social-liberal features, which implies that it is relevant to explore these interaction effects further. The coefficient sizes are slightly larger for social-liberal features than for thin liberal features. While we can compare coefficient sizes between different features as they are on the same scale, we cannot compare coefficients between the electoral democracy index and the different democracy features, as they are measured on different scales. We can, however, compare $\mathrm{R}^{2}$ statistics and this shows that the model with the social-liberal features index has the highest score, although the difference is trivial. We further build marginal effects plots to compare the relationship between the number of laws and $\mathrm{CO}_{2}$ emissions in democracies with different features.

The marginal effects plots, presented in Figure 1, show that the strongest effect from the number of climate laws on $\mathrm{CO}_{2}$ emissions, represented by a steeper slope, is among the democracies with more pronounced thin liberal and social-liberal features. This implies that as countries develop more liberal (in its thin conception) and social-liberal features they also tend to be more successful in translating their climate laws into the reduction of $\mathrm{CO}_{2}$ emission intensity. Development of the deliberative democracy features does not seem to play a role in determining whether the adopted climate laws mean a reduction in $\mathrm{CO}_{2}$ emissions. 
Table 3. The relationship between thin liberal, social-liberal, and deliberative features and the effectiveness of climate laws in democracies

\begin{tabular}{|c|c|c|c|c|}
\hline $\mathrm{DV}: \ln \left(\mathrm{CO}_{2} / \mathrm{GDP}\right)$ & Model 1 & Model 2 & Model 3 & Model 4 \\
\hline Electoral democracy & $\begin{array}{l}-0.066 \\
(0.109)\end{array}$ & & & \\
\hline Stock of laws*Elect.dem & $\begin{array}{l}-0.020 \\
(0.021)\end{array}$ & & & \\
\hline Thin liberal features & & $\begin{array}{c}-0.040^{*} \\
(0.020)\end{array}$ & & \\
\hline Stock of laws*Thin liberal & & $\begin{array}{c}-0.010 \dagger \\
(0.006)\end{array}$ & & \\
\hline Social-liberal features & & & $\begin{array}{l}0.135 \dagger \\
(0.080)\end{array}$ & \\
\hline Stock of laws*Social-liberal & & & $\begin{array}{l}-0.006 \dagger \\
(0.003)\end{array}$ & \\
\hline Deliberative features & & & & $\begin{array}{l}-0.030 \\
(0.032)\end{array}$ \\
\hline Stock of laws*Deliberative & & & & $\begin{array}{c}0.005 \\
(0.006)\end{array}$ \\
\hline Stock of mitigation laws & $\begin{array}{c}0.010 \\
(0.018)\end{array}$ & $\begin{array}{c}0.033 \\
(0.022)\end{array}$ & $\begin{array}{c}0.016 \\
(0.012)\end{array}$ & $\begin{array}{l}-0.024 \\
(0.024)\end{array}$ \\
\hline Constant & $\begin{array}{c}-11.715^{* * *} \\
(3.292)\end{array}$ & $\begin{array}{c}-12.365^{* * *} \\
(3.193)\end{array}$ & $\begin{array}{c}-11.221^{* *} \\
(3.374)\end{array}$ & $\begin{array}{c}-11.934 * * * \\
(3.231)\end{array}$ \\
\hline Observations & 1,480 & 1,480 & 1,480 & 1,480 \\
\hline $\mathrm{R}^{2}$ & 0.476 & 0.484 & 0.485 & 0.477 \\
\hline Number of countries & 94 & 94 & 94 & 94 \\
\hline Year fixed effects & yes & yes & yes & yes \\
\hline
\end{tabular}

OLS regression of a natural logarithm of $\mathrm{CO}_{2}$ emissions per 2011 PPP \$1 GDP on the interaction effect between the stock of laws and different democracy features, with country and year fixed effects. The sample contains world democracies as classified by Bjørnskov-Rode (2020). The regressions control for the GDP HP filter, squared term of GDP per capita (natural log), the size of imports and services as a percentage of GDP, difference between the yearly average temperature and the long term (1980-2015) average temperature, and federalism. Robust standard errors in parentheses, ${ }^{* * *} \mathrm{p}<0.001,{ }^{* *} \mathrm{p}<0.01, * \mathrm{p}<0.05, \dagger \mathrm{p}<0.1$. All independent variables are lagged 1 year. 
1) Conditional marginal effect of $N$ Laws

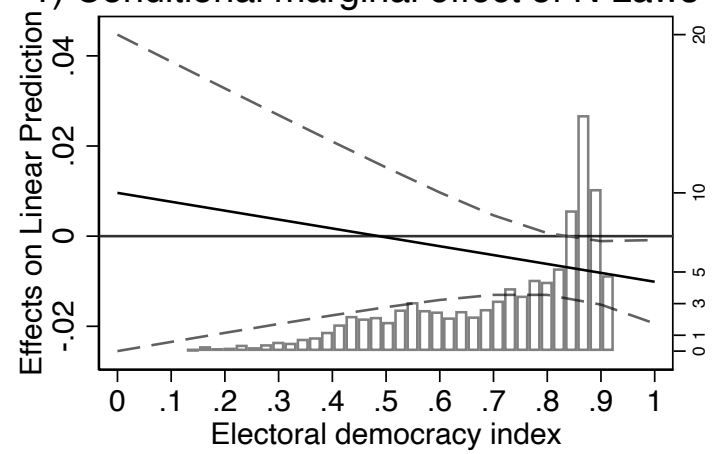

3) Conditional Marginal Effect of N Laws

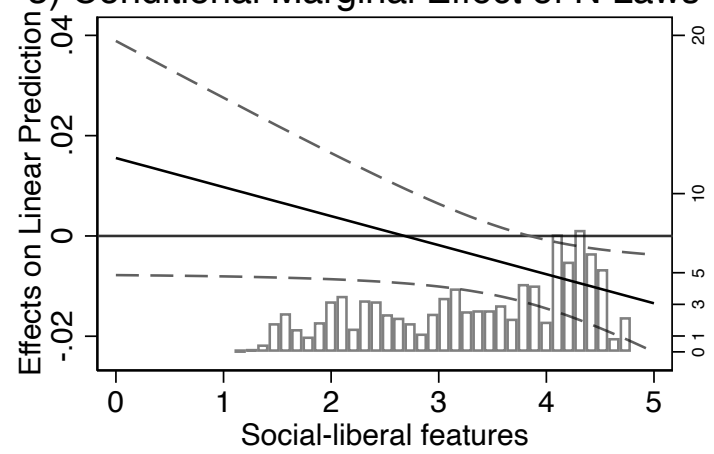

2) Conditional Marginal Effect of N Laws

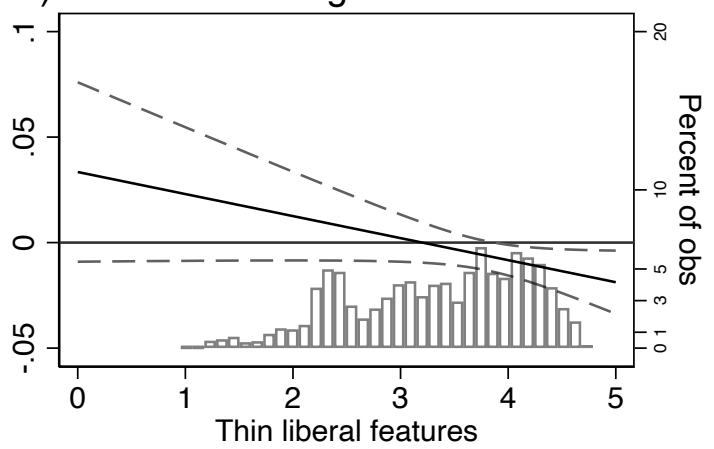

4) Conditional Marginal Effect of $N$ Laws

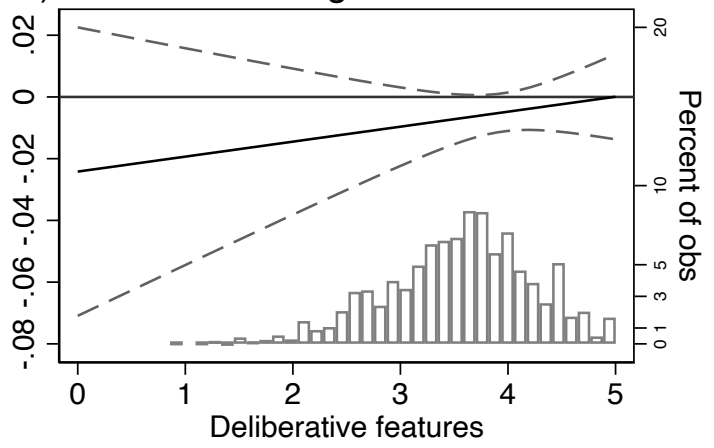

Figure 1. Marginal effects of the stock of recent climate change mitigation laws on $\mathrm{CO}_{2}$ emissions conditional on the level of electoral democracy (1), extent of thin liberal features (2), social-liberal features (3), and deliberative features (4) in democracies, with $95 \%$ confidence intervals.

Table 4 presents the results for equation 2, where the dependent variable is the Environmental Policy Stringency Index from the OECD database. The sample covers OECD countries and the six BRIICS economies. Model 1 presents the relationship between the electoral democracy index and environmental policy stringency (EPS), Models 2-4 - the relationship between thin liberal, social-liberal, and deliberative features respectively, while Model 5 shows the results when all three indices are included in one model, testing whether one of them is a stronger predictor than the rest. The table is divided into two parts. The upper part contains coefficients from the between-analysis that show the relationship between democracies, while the lower part of the table contains the coefficients from the analysis of variation within democracies, based on changes over time.

The results show that democracies with more pronounced liberal (in its thin conception) and social-liberal features have higher environmental policy stringency than democracies with less 
pronounced thin liberal and social-liberal features. The coefficient on the social-liberal index is higher, implying that its effect on environmental policy stringency is stronger. When all three democracy features are included in one model for comparison, democracies with pronounced social-liberal and deliberative features have significant coefficients, however, the deliberative index is only significant at $10 \%$, and the social-liberal index still has the highest effect size, implying that democracies with prevalent social-liberal features have higher environmental policy stringency than democracies with other dominating features.

The results for the analysis of changes within countries showed that developments towards higher deliberation are actually associated with negative trends in environmental policy stringency. This implies that there might be a negative relationship between deliberation and environmental policy stringency. This result holds even when all three indices are included in one model for comparison.

Comparison of the $\mathrm{R}^{2}$ statistics shows that the model with the social-liberal index has the highest $\mathrm{R}^{2}$ in the between-sample and the model with the deliberative index has the highest $\mathrm{R}^{2}$ for the within-sample. This implies that the model with the social-liberal index explains the highest proportion of variance in a dependent variable between countries and the model with the deliberative index - the highest proportion of variance in the dependent variable in the withinsample.

The coefficients for all control variables are in the expected direction. What particularly stands out is the strong negative association between corruption and environmental policy stringency, both in the within- and the between- analysis, implying that countries with higher corruption have lower environmental policy stringency and an increase in corruption levels is associated with a decrease in policy stringency. 
Table 4. The relationship between thin liberal, social-liberal, and deliberative features and environmental policy stringency in the democracies of OECD and BRIICS

\begin{tabular}{|c|c|c|c|c|c|}
\hline DV: EPS & Model 1 & Model 2 & Model 3 & Model 4 & Model 5 \\
\hline Between part: & & & & & \\
\hline Electoral democracy & $\begin{array}{c}0.514 \\
(1.355)\end{array}$ & & & & \\
\hline Thin liberal features & & $\begin{array}{l}0.228 \dagger \\
(0.136)\end{array}$ & & & $\begin{array}{c}0.219 \\
(0.143)\end{array}$ \\
\hline Social-liberal features & & & $\begin{array}{c}0.377 * * * \\
(0.102)\end{array}$ & & $\begin{array}{c}0.305^{* * *} \\
(0.086)\end{array}$ \\
\hline Deliberative features & & & & $\begin{array}{c}0.253 \\
(0.201)\end{array}$ & $\begin{array}{l}0.288 \dagger \\
(0.175)\end{array}$ \\
\hline GDP per capita (ln) & $\begin{array}{c}0.002 \\
(0.005)\end{array}$ & $\begin{array}{l}-0.000 \\
(0.005)\end{array}$ & $\begin{array}{c}0.001 \\
(0.005)\end{array}$ & $\begin{array}{l}-0.001 \\
(0.006)\end{array}$ & $\begin{array}{l}-0.006 \\
(0.006)\end{array}$ \\
\hline Trade openness & $\begin{array}{c}1.137 \\
(2.539)\end{array}$ & $\begin{array}{c}0.691 \\
(2.449)\end{array}$ & $\begin{array}{l}-0.020 \\
(2.279)\end{array}$ & $\begin{array}{c}1.095 \\
(1.970)\end{array}$ & $\begin{array}{l}-0.189 \\
(1.853)\end{array}$ \\
\hline Time in the EU & $\begin{array}{c}0.005 \\
(0.004)\end{array}$ & $\begin{array}{c}0.004 \\
(0.004)\end{array}$ & $\begin{array}{c}0.005 \\
(0.003)\end{array}$ & $\begin{array}{c}0.005 \\
(0.003)\end{array}$ & $\begin{array}{c}0.003 \\
(0.003)\end{array}$ \\
\hline Corruption & $\begin{array}{c}-1.914^{* *} \\
(0.725)\end{array}$ & $\begin{array}{c}-1.768^{* * *} \\
(0.319)\end{array}$ & $\begin{array}{c}-1.226^{* * *} \\
(0.318)\end{array}$ & $\begin{array}{c}-1.570^{* * *} \\
(0.351)\end{array}$ & $\begin{array}{c}-0.721 * \\
(0.309)\end{array}$ \\
\hline
\end{tabular}

Within part:

Electoral democracy $\quad 1.028$

(1.144)

Thin liberal features

0.008

0.028

$(0.187)$

(0.154)

Social-liberal features

0.309

0.396

(0.322)

$(0.301)$

Deliberative features

$\begin{array}{cccc} & & -0.584^{*} & -0.609 * \\ & & (0.290) & (0.298) \\ 0.027 \dagger & 0.026 & 0.021 & 0.019 \\ (0.015) & (0.016) & (0.014) & (0.015) \\ 0.267 & 0.637 & -1.314 & -1.294 \\ (5.743) & (5.649) & (5.124) & (5.241) \\ 0.007 & 0.006 & 0.006 & 0.005 \\ (0.014) & (0.013) & (0.013) & (0.012) \\ -1.811 & -1.558 & -3.705^{* *} & -3.390^{* *} \\ (1.124) & (1.056) & (1.176) & (1.224) \\ 0.370 & -0.368 & 0.111 & -1.948 \dagger \\ (0.391) & (0.418) & (0.733) & (1.029)\end{array}$

\begin{tabular}{lccccc} 
Observations & 671 & 671 & 671 & 671 & 671 \\
$\mathrm{R}^{2}$ between & 0.613 & 0.626 & 0.702 & 0.624 & 0.708 \\
$\mathrm{R}^{2}$ within & 0.808 & 0.807 & 0.808 & 0.819 & 0.821 \\
Number of countries & 31 & 31 & 31 & 31 & 31 \\
Year fixed effects & yes & yes & yes & yes & yes \\
\hline
\end{tabular}

Within-between regression of environmental policy stringency on different democracy features with year fixed effects in the OECD and BRIICS. The sample is limited to democracies as classified by Bjørnskov-Rode (2020). Both within- and between-parts of the equation include controls for the GDP per capita (natural log), trade openness, time in the EU, and corruption. Robust standard errors in parentheses, ${ }^{* * *} \mathrm{p}<0.001,{ }^{* *} \mathrm{p}<0.01, *$ $\mathrm{p}<0.05, \uparrow \mathrm{p}<0.1$. All independent variables are lagged 1 year. 
Table 5 presents the results for the relationship between the different democracy features and a measure of 'environmental efforts' in the developing countries from the Bertelsmann Stiftung's Transformation Index. Similar to the previous tables, Model 1 presents the results for the estimation of the relationship between the electoral democracy index and the measure of environmental efforts, Models 2-4 - for the thin-liberal, social-liberal, and deliberative democracy features respectively, while Model 5 - for all three indices included simultaneously in the estimation. The comparison of the coefficients for the different democracy features indicates that social-liberal features have the strongest association with environmental efforts among developing countries, and that the social-liberal index is the only one significant. Moreover, the between-model with the social-liberal index as a predictor has the largest $\mathrm{R}^{2}$. When all three indices are included in one model (Model 5), the social-liberal index is also the only one that has a statistically significant coefficient, implying that democracies with strong traces of social-liberal features make greater environmental efforts than other democracies in the developing world. In the within-sample, the results are insignificant. 
Table 5. The relationship between thin liberal, social-liberal, and deliberative features and environmental efforts in developing countries

\begin{tabular}{|c|c|c|c|c|c|}
\hline DV: Environmental efforts & Model 1 & Model 2 & Model 3 & Model 4 & Model 5 \\
\hline \multicolumn{6}{|l|}{ Between part: } \\
\hline Electoral democracy & $\begin{array}{c}0.687 \\
(1.174)\end{array}$ & & & & \\
\hline \multirow[t]{2}{*}{ Thin liberal features } & & 0.022 & & & 0.088 \\
\hline & & $(0.230)$ & & & $(0.208)$ \\
\hline \multirow[t]{2}{*}{ Social-liberal features } & & & $0.390 \dagger$ & & $0.409 *$ \\
\hline & & & $(0.206)$ & & $(0.204)$ \\
\hline \multirow[t]{2}{*}{ Deliberative features } & & & & 0.054 & 0.055 \\
\hline & & & & $(0.281)$ & $(0.273)$ \\
\hline \multirow[t]{2}{*}{ GDP per capita (ln) } & $0.481^{* *}$ & $0.499 * *$ & $0.415^{* *}$ & $0.507 * *$ & $0.396^{*}$ \\
\hline & $(0.161)$ & $(0.179)$ & $(0.142)$ & $(0.157)$ & $(0.167)$ \\
\hline \multirow[t]{2}{*}{ Trade openness } & 0.424 & 0.368 & 0.174 & 0.388 & 0.149 \\
\hline & $(0.265)$ & $(0.251)$ & $(0.266)$ & $(0.242)$ & $(0.271)$ \\
\hline \multirow[t]{2}{*}{ Time in the EU } & $-1.810^{*}$ & $-2.034 * *$ & $-1.548^{*}$ & $-1.963^{* *}$ & $-1.436 \dagger$ \\
\hline & $(0.715)$ & $(0.638)$ & $(0.680)$ & $(0.691)$ & $(0.762)$ \\
\hline \multirow[t]{2}{*}{ Corruption } & $0.186^{* * *}$ & $0.195^{* * *}$ & $0.188^{* * *}$ & $0.195^{* * *}$ & $0.187^{* * *}$ \\
\hline & $(0.053)$ & $(0.052)$ & $(0.048)$ & $(0.051)$ & $(0.047)$ \\
\hline \multicolumn{6}{|l|}{ Within part: } \\
\hline \multirow[t]{2}{*}{ Electoral democracy } & 1.120 & & & & \\
\hline & $(0.849)$ & & & & \\
\hline \multirow[t]{2}{*}{ Thin liberal features } & & 0.092 & & & 0.095 \\
\hline & & $(0.173)$ & & & $(0.170)$ \\
\hline \multirow[t]{2}{*}{ Social-liberal features } & & & 0.291 & & 0.313 \\
\hline & & & $(0.359)$ & & $(0.374)$ \\
\hline \multirow[t]{2}{*}{ Deliberative features } & & & & -0.043 & -0.051 \\
\hline & & & & $(0.153)$ & $(0.157)$ \\
\hline \multirow[t]{2}{*}{ GDP per capita (ln) } & 0.189 & 0.265 & 0.303 & 0.321 & 0.207 \\
\hline & $(0.682)$ & $(0.693)$ & $(0.683)$ & $(0.680)$ & $(0.705)$ \\
\hline \multirow[t]{2}{*}{ Trade openness } & -0.157 & -0.232 & -0.214 & -0.239 & -0.230 \\
\hline & $(0.282)$ & $(0.273)$ & $(0.277)$ & $(0.267)$ & $(0.270)$ \\
\hline \multirow[t]{2}{*}{ Time in the EU } & -0.984 & $-1.537 \dagger$ & -1.471 & $-1.609 \dagger$ & $-1.597 \dagger$ \\
\hline & $(0.878)$ & $(0.923)$ & $(0.915)$ & $(0.975)$ & $(0.966)$ \\
\hline \multirow[t]{2}{*}{ Corruption } & -0.006 & -0.005 & 0.001 & -0.004 & 0.002 \\
\hline & $(0.040)$ & $(0.042)$ & $(0.043)$ & $(0.042)$ & $(0.043)$ \\
\hline \multirow[t]{2}{*}{ Constant } & $3.325 \dagger$ & $4.057 * * *$ & $3.682^{* * *}$ & $3.840^{*}$ & $3.215 \dagger$ \\
\hline & $(1.752)$ & $(1.036)$ & $(1.063)$ & $(1.743)$ & $(1.817)$ \\
\hline Observations & 415 & 415 & 415 & 415 & 415 \\
\hline $\mathrm{R}^{2}$ between & 0.705 & 0.700 & 0.714 & 0.699 & 0.714 \\
\hline $\mathrm{R}^{2}$ within & 0.086 & 0.080 & 0.083 & 0.081 & 0.084 \\
\hline Number of countries & 69 & 69 & 69 & 69 & 69 \\
\hline Year fixed effects & yes & yes & yes & yes & yes \\
\hline
\end{tabular}

Within-between regression of 'environmental efforts' in the developing world on different democracy features, with year fixed effects. The sample is limited to democracies as classified by Bjørnskov-Rode (2020). Both withinand between-parts of the equation include controls for the GDP per capita (natural log), trade openness, time in the EU, and corruption. Robust standard errors in parentheses, ${ }^{* * *} \mathrm{p}<0.001,{ }^{* *} \mathrm{p}<0.01,{ }^{*} \mathrm{p}<0.05, \dagger \mathrm{p}<0.1$. All independent variables are lagged 1 year. 
In order to compare the environmental commitments of democracies with thin liberal, socialliberal, and deliberative features with those of authoritarian regimes, we performed the same sets of analyses for the full sample of countries, multiplying our indicators with a democracy dummy from Bjørnskov and Rode (2020). The results are presented in Appendix D and they are similar to the results in the full sample. Democracies with thin liberal and social liberal features outperform authoritarian regimes in translating their climate laws into $\mathrm{CO}_{2}$ emission reductions to a stronger degree than the rest. Democracies with developed social-liberal features among OECD and BRIIC have higher environmental policy stringency than the rest, and the coefficient for deliberative democracy is no longer significant when the three democracy indicators are included in the same model. In the sample of developing countries, democracies with socialliberal features also outperform authoritarian regimes in terms of environmental commitment to a stronger degree than democracies with other features. In the within-sample, however, the only significant result is for the electoral democracy index, which implies that developments in the level of democracy might be more important for strengthening environmental efforts in the developing world when compared to authoritarian regimes, than developments in any additional democracy features. The same conclusion can be made when comparing the $\mathrm{R}^{2}$ between the models - the model with the electoral democracy index as the independent variable explains more variance in environmental efforts than other models; more than the model with the socialliberal democracy index.

We also investigated whether arguments brought up in the green political theory literature apply to non-democracies, that is, whether thin liberal, social-liberal and deliberative features play a role when we compare all countries regardless of their regime type. The results, presented in Appendix E, are similar to the ones described above and imply that liberal features in their thin understanding, social-liberal features and deliberation might also be important for establishing environmental commitments in non-democracies.

In order to check the robustness of our results, we also used indicators of liberal, social-liberal (egalitarian) and deliberative features from the Varieties of Democracy institute as independent variables instead of our own indices. We found that our results in favour of social-liberal (egalitarian) democracy, and egalitarian features overall, among all regime types, are even stronger with the V-Dem measures (see Appendix F for results). Liberal democracies do not seem to do better than the rest, even though the indicators pertaining to rule of law are included in the coding. 


\section{Summary of the results}

In sum, the results indicate that democracies with developed social-liberal features outperform other democracies and authoritarian regimes in securing environmental commitments. The differences in the strength of association vary between the models. In the case of emission reductions, democracies with thin liberal features seem to be doing just as well as democracies with developed social-liberal features, and the explanatory power of the model with the socialliberal index is only slightly higher than that of the model with the thin liberal index. In the case of environmental policy stringency and environmental efforts, the differences between the effect size of thin liberal and social-liberal features are larger, yet still rather small. The weakest predictor of environmental commitments seems to be deliberative features, as its effect size is the smallest out of the three democracy types and is, for the most part, insignificant. Moreover, we even find a negative relationship between the deliberative democracy features and environmental policy stringency. We would also like to note that in the sample of developing countries, when the performance of democracy types is compared to that of authoritarian regimes, the level of democracy itself seems to be a more important predictor of stronger environmental efforts than the additional features of democracy.

\section{Discussion and Conclusions}

The aim of this study has been to investigate how countries that are (empirically) more or less associated with different democracy ideals perform in terms of their environmental commitments. Taking as a point of departure the theories on how the dominance of liberal values, in their thin interpretation, social-liberal traditions, and deliberative practices can influence the environmental commitments of states, we challenge fifty years of green political theoretical scholarship and put the established theoretical arguments to an empirical test.

The results generally speak in favour of democracy with pronounced social-liberal features: democratic OECD-BRIIC countries with pronounced social-liberal features have significantly higher environmental policy stringency. In parallel, democracies with social-liberal features in the developing world also make greater environmental efforts than the rest. This implies that countries that carry out social-liberal politics, which results in higher equality among citizens in their access to public services such as healthcare and education, the prevalence of universalistic over means-tested policies, and higher spending on public rather than particularistic goods, tend to also adopt more stringent environmental policies, possibly as an example of such universalistic policies, compared to countries leaning towards any of the other ideals that we have examined. 
Remarkably, this result is not driven by the exceptional social-liberal traditions of Northern Europe only, but is also true for countries in the developing world.

The development of thin liberal features in democracies has as strong an association with $\mathrm{CO}_{2}$ emission reductions following the adoption of climate laws and policies as the development of social-liberal features. This might imply that market-based policy instruments, usually applied in democracies with strong markets, might be as effective in reducing greenhouse gas emissions as taxes, usually used by democracies following a more social-liberal model. However, this insight needs further investigation before more definite conclusions can be drawn, especially given that policy instruments are now increasingly applied in policy packages rather than separately (Wicki, Huber, \& Bernauer, 2020) and are being adopted in an increasing number of countries, not all of which could be characterized as social-liberal.

Finally, deliberative features have the weakest association with environmental commitments among the three democracy features investigated in the paper. Our models even show that development in deliberation is associated with a decrease in environmental policy stringency among the OECD-BRIIC economies. This goes against the prediction of green political theories advocating deliberative democracy as a solution to environmental problems. Without knowing for certain, this might at least imply that as countries open up channels for deliberation, this also gives voice to anti-environmental interests, which might trump environmental interests, and provoke a decrease in the stringency of environmental policies. However, the negative result for deliberative democracy needs further exploration before we can draw this conclusion with any certainty. In addition, it could be that different types of democracy provide channels for facilitating different types of environmental policies. While thin liberal and social-liberal features are more suitable for emission mitigation policies, deliberation could be beneficial for policies related to adaptation to environmental problems (Ayers, 2011), which we do not investigate in this paper.

Moreover, while there are empirical examples of countries with particularly pronounced socialliberal features (Nordic countries) and thin liberal features (the United States and the United Kingdom), the examples of countries with pronounced deliberative practices, properly understood as deliberative democracies in political theory, are significantly harder to find. Therefore, it could be that the lack of effect from deliberation is driven by the fact that no country has so far reached a deliberative democratic ideal. Having said this, the results may still be of value. Although it might be an ideologically attractive idea to be inclusive and to involve 
interest groups and the general public in decision-making processes, the expected environmental effectiveness of such operations should not be exaggerated.

Our analyses also generate some implications for green political theory and the pronounced criticism of thin liberal democracy over the years. Our empirical analysis shows that democracies that develop the thin liberal features being so criticized in the literature, do not perform significantly worse than the others, and in fact they exhibit comparable results to those of socialliberal democracies when it comes to, for example, reducing carbon emission intensity. This can be a result of the fact that thin liberal features often go together with some degree of rule of law and constraints on the executive, each of which are important for securing long-term environmental commitments.

Finally, another limitation of the existing theories is that they, by only focusing on democracy features, overlook the importance of the factors that they discuss in reference to non-democratic regimes. However, their arguments are also relevant for understanding environmental commitments in non-democracies. In fact, our analysis shows that a more social-liberal politics is beneficial for countries' environmental commitments regardless of the regime type. Future research should continue testing the relationship between the democratic ideals outlined in this article and various measures of environmental commitment as more data becomes available. Using process tracing approaches, future studies can also investigate - more qualitatively - how the hypothesized effect of thin liberal, deliberative, and social-liberal features have played out for the environmental commitments of countries that practiced these types of democratic politics. 


\section{References}

Achterberg, W. (1993). Can liberal democracy survive the environmental crisis. In A. Dobson \& P. Lucardie (Eds.), The Politics of nature: Explorations in green political theory (pp. 81-101). London; New York: Routledge.

Arvin, M. B., \& Lew, B. (2011). Does democracy affect environmental quality in developing countries? Applied Economics, 43(9), 1151-1160. https://doi.org/10.1080/00036840802600277

Ayers, J. (2011). Resolving the adaptation paradox: Exploring the potential for deliberative adaptation policy-making in Bangladesh. Global Environmental Politics, 11(1), 62-88. https://doi.org/10.1162/GLEP_a_00043

Bäckstrand, K., Khan, J., Kronsell, A., \& Lövbrand, E. (2010). Environmental politics and deliberative democracy: Examining the promise of new modes of governance. In Environmental Politics and Deliberative Democracy: Examining the Promise of New Modes of Governance. https://doi.org/10.4337/9781849806411

Barns, I. (1995). Environment, Democracy and Community. Environmental Politics, 4(4), 101-133. https://doi.org/10.1080/09644019508414230

Barrett, S., \& Graddy, K. (2000). Freedom, growth, and the environment. Environment and Development Economics, 5(04), 433-456. https://doi.org/doi:null

Barry, J. (2014). Rethinking Green Politics: Nature, Virtue and Progress. In Rethinking Green Politics: Nature, Virtue and Progress. https://doi.org/10.4135/9781446279311

Bättig, M. B., \& Bernauer, T. (2009). National institutions and global public goods: are democracies more cooperative in climate change policy? International Organization, 63(02), 281-308.

Bernauer, T., \& Koubi, V. (2009). Effects of political institutions on air quality. Ecological Economics, 68(5), 1355-1365.

Biermann, F. (2014). Earth system governance: World politics in the Anthropocene. MIT Press.

Bjørnskov, C., \& Rode, M. (2020). Regime types and regime change: A new dataset on democracy, coups, and political institutions. The Review of International Organizations, 15, 531551. https://doi.org/0.1007/s11558-019-09345-1

Botta, E., \& Koźluk, T. (2014). Measuring Environmental Policy Stringency in OECD Countries. In OECD Economics Department Working Papers 1177. https://doi.org/10.1787/5jxrjnc45gvg-en

Burch, S., Gupta, A., Inoue, C. Y. A., Kalfagianni, A., Persson, A., Gerlak, A. K., ... Scobie, M. (2019). New directions in earth system governance research. Earth System Governance, 1, 
100006.

Cheibub, J. A., Gandhi, J., \& Vreeland, J. R. (2010). Democracy and dictatorship revisited. Public Choice, 143(1-2), 67-101.

Climate Change Laws of the World database. (2020). Grantham Research Institute on Climate Change and the Environment and Sabin Center for Climate Change Law. Retrieved from climate-laws.org

Coppedge, M., Gerring, J., Knutsen, C. H., Lindberg, S. I., Teorell, J., Altman, D., ... Ziblatt, D. (2020). V-Dem [Country-Year/Country-Date] Dataset v10. Varieties of Democracy ( $V$-Dem) Project.

Coppedge, M., Gerring, J., Knutsen, C. H., Lindberg, S. I., Teorell, J., Altman, D., ... Ziblatt, D. (2020). V-Dem Codebook v10. Varieties of Democracy (V-Dem) Project: University of Gothenburg.

Dahl, R. A. (1971). Polyarchy: Participation and opposition. Yale University Press.

De-Shalit, A. (2000). The environment: Between theory and practice. Oxford: Oxford University Press.

De Geus, M. (2001). Sustainability, liberal democracy, liberalism. In J. Barry \& M. Wissenburg (Eds.), Sustaining liberal democracy (pp. 19-36). London: Palgrave Macmillan.

Dobson, A. (2007). Green Political Thought. In Green Political Thought (3rd editio). https://doi.org/10.4324/9780203964620

Donner, S., Hartmann, H., \& Schwarz, R. (2020). Transformation Index of the Bertesmann Stiftung. Retrieved from http://www.bti-project.org

Dryzek, J. S. (1987). Rational ecology: environment and political economy. New York: Basil Blackwell.

Dryzek, J. S. (1990). Discursive democracy: Politics, policy, and political science. Cambridge: Cambridge University Press.

Dryzek, J. S. (1992). Ecology and Discursive Democracy: Beyond Liberal Capitalism and the Administrative State. Capitalism Nature Socialism, 3(2), 18-42. https://doi.org/10.1080/10455759209358485

Dryzek, J. S. (2001). Legitimacy and economy in deliberative democracy. Political Theory, 29(5), 651-669. https://doi.org/10.1177/0090591701029005003

Dryzek, J. S. (2011). Foundations and Frontiers of Deliberative Governance. In Foundations and Frontiers of Deliberative Governance (Vol. 9780199562). https://doi.org/10.1093/acprof:oso/9780199562947.001.0001

Dworkin, R., \& Dworkin, R. (1981). What is Equality?: Part 2: Equality of Resources. Philosophy \& Public Affairs, 10(4), 283-345.

Eckersley, R. (1995). Liberal Democracy and the Rights of Nature: The Struggle For Inclusion. 
Environmental Politics, 4(4), 169-198. https://doi.org/10.1080/09644019508414232

Eckersley, R. (1997). Green justice, the state and democracy. Environmental Justice: Global Ethics for the 21st Century Conference at Melbourne University, 169-199.

Eckersley, R. (2004). The green state: rethinking democracy and sovereignty. Cambridge, Mass.; London: MIT Press.

Ehrlich, P. (2013). The population bomb. In The Future of Nature: Documents of Global Change. https://doi.org/10.9774/gleaf.978-1-907643-44-6_6

Eskander, S. M. S. U., \& Fankhauser, S. (2020). Reduction in greenhouse gas emissions from national climate legislation. Nature Climate Change, 10(8), 750-756.

Fraser Institute. (2020). 2020 Economic Freedom Dataset. Retrieved from https://www.fraserinstitute.org/ economic-freedom/dataset

Fredriksson, P. G., \& Wollscheid, J. R. (2007). Democratic institutions versus autocratic regimes: The case of environmental policy. Public Choice, 130(3-4), 381-393. https://doi.org/10.1007/s11127-006-9093-1

Gewirth, A. (1978). On Reason and Morality. Chicago: University of Chicago Press.

Gleditsch, N. P., \& Sverdrup, B. O. (2003). Democracy and the Environment. In E. Paper \& M. Redclift (Eds.), Human Security and the Environment: International Comparison. Cheltenham; Northampton MA: Edward Elgar Publishing.

Hayward, T. (1998). Political theory and ecological values. Retrieved from http://www.loc.gov/catdir/bios/hol057/98011701.html\%5CnMaterials specified: Contributor biographical information http://www.loc.gov/catdir/bios/hol057/98011701.html\%5CnMaterials specified: Publisher description http://www.loc.gov/catdir/description/hol056

Heilbroner, R. L. (1974). An inquiry into the human prospect (1st ed.). New York,: Norton.

Held, D. (1997). Democracy and globalization. Global Governance: A Review of Multilateralism and International Organizations, 3(3), 251-267.

Inglehart, R., \& Welzel, C. (2005). Modernization, cultural change, and democracy: The buman development sequence. Cambridge University Press.

Jacobs, M. (1996). The politics of the Real World: meeting the new century. In The politics of the Real World: meeting the new century. London: Earthscan.

Jagers, S. C. (2007). Prospects for green liberal democracy. Lanham, Md.: University Press of America.

Kelbley, C. (1989). The Morality of Freedom. In International Philosophical Quarterly (Vol. 29). https://doi.org/10.5840/ipq198929152

Kennedy, P. M. (1993). Preparing for the twenty-first century. London: HarperCollins. 
Lafferty, W. M., \& Meadowcroft, J. (1996). Democracy and the environment: congruence and conflict - preliminary reflections. In Democracy and the Environment: Problems and prospects (pp. 1-17). Cheltenham: Edward Elgar Pub.

Li, Q., \& Reuveny, R. (2006). Democracy and Environmental Degradation. International Studies Quarterly, 50(4), 935-956. https://doi.org/10.2307/4092786

Lindberg, S. I., Coppedge, M., Gerring, J., \& Teorell, J. (2014). V-Dem: A New Way to Measure Democracy. Journal of Democracy, 25(3), 159-169.

Mathews, F. (1995). Community and the Ecological Self. Environmental Politics, 4(4), 66-100. https://doi.org/10.1080/09644019508414229

Mill, J. S. (1884). Principles of Political Economy (Vol. 1). New York: D. Appleton.

Neumayer, E. (2002). Do Democracies Exhibit Stronger International Environmental Commitment? A Cross-Country Analysis. Journal of Peace Research, 39(2), 139-164. https://doi.org/10.2307/1555296

Ophuls, W. (1977). Ecology and the politics of scarcity : prologue to a political theory of the steady state. San Francisco: W. H. Freeman.

Ostrom, E. (1990). Governing the commons: the evolution of institutions for collective action. Cambridge; New York: Cambridge University Press.

Paehlke, R. (1995). Environmental values for a sustainable society: the democratic challenge. In F. Fischer \& M. Black (Eds.), Greening Environmental Policy (pp. 129-144). https://doi.org/10.1007/978-1-137-08357-9_8

Pemstein, D., Marquardt, K. L., Tzelgov, E., Wang, Y., Medzihorsky, J., Krusell, J., ... von Römer, J. (2020). The V-Dem Measurement Model: Latent Variable Analysis for CrossNational and Cross-Temporal Expert-Coded Data. In V-Dem Working Paper No. 21, 5th edition. University of Gothenburg: Varieties of Democracy Institute.

Povitkina, M. (2018). The limits of democracy in tackling climate change. Environmental Politics, 27(3), 411-432. https://doi.org/10.1080/09644016.2018.1444723

Povitkina, M., \& Bolkvadze, K. (2019). Fresh pipes with dirty water: How quality of government shapes the provision of public goods in democracies. European Journal of Political Research, 58(4), 1191-1212. https://doi.org/10.1111/1475-6765.12330

Radcliffe, J. (2000). Green Politics. In J. Campling (Ed.), Green Politics. https://doi.org/10.1057/9780333981696

Randers, J. (2012). 2052: A global forecast for the next forty years. Chelsea Green Publishing.

Rawls, J. (1972). A theory of justice. Oxford: Clarendon Press.

Sen, A. (1988). Freedom of choice. Concept and content. European Economic Review, 32(2-3), 269- 
294. https://doi.org/10.1016/0014-2921(88)90173-0

Sen, A. (1992). Inequality reexamined. Oxford University Press.

Sjöstedt, M., \& Jagers, S. C. (2014). Democracy and the environment revisited: The case of African fisheries. Marine Policy, 43, 143-148.

Smith, G. (2003). Deliberative democracy and the environment. London, New York: Routledge.

Spilker, G. (2013). Globalization, Political Institutions and the Environment in Developing Countries (Vol. 3). New York, London: Routledge.

Stephens, J. (1999). Just Institutions Matter: The Moral and Political Logic of the Universal Welfare State . Bo Rothstein. In The Journal of Politics (Vol. 61). https://doi.org/10.2307/2647794

Teorell, J., Dahlberg, S., Holmberg, S., Rothstein, B., Alvarado Pachon, N., \& Axelsson, S. (2020). The Quality of Government Standard Dataset, version Jan20. https://doi.org/18157/qogstdjan20

Wallace, A. (1998). Between Facts and Norms: Contributions to a Discourse Theory of Law and Democracy. Jürgen Habermas . In Ethics (Vol. 108). https://doi.org/10.1086/233838

Wicki, M., Huber, R. A., \& Bernauer, T. (2020). Can policy-packaging increase public support for costly policies? Insights from a choice experiment on policies against vehicle emissions. Journal of Public Policy, 40(4), 599-625.

World Bank. (2016). World Development Indicators. Retrieved from The World Bank website: https://data.worldbank.org/products/wdi

World Commission on Environment and Development. (1987). Our common future. Retrieved from http://www.un-documents.net/wced-ocf.htm 


\section{Appendix A. Data included in the construction of indices.}

\section{Thin liberal features}

When choosing indicators, we were guided by the data availability and how precisely the indicators can capture countries' liberal features in their thin conception. In terms of data availability, the Fraser Index of Economic Freedom of the World (Fraser Institute, 2020) had the most comprehensive dataset on individual and business freedom that was possible to get disaggregated data on. We opted for using as many indicators as possible that tap on individual and business freedom from the government regulation and deliberately excluded indicators related to regulatory quality, rule of law and ease of doing business, as they tap upon other features of political systems than thin liberal features. When constructing a latent variable through a factor analysis included the following indicators:

\subsection{Size of government index}

The index ranges from $0-10$ where 0 corresponds to large general government consumption, large transfer sector, many government enterprises, and high marginal tax rates and low income thresholds, and 10 to small general government consumption, small transfer sector, few government enterprises, and low marginal tax rates and high income thresholds.

The index consists of the following indicators:

- General government consumption spending as a percentage of total consumption

- Transfers and subsidies as a percentage of GDP

- Government enterprises and investment as a percentage of total investment

- Top marginal tax rate (and income threshold to which it applies).

The index is panel-data adjusted.

\subsection{Protection of property rights.}

The indicator originates from the Global Competitiveness Report by the World Economic Forum and measures the extent to which "Property rights, including over financial assets, are defined and protected." In the original indicator, if property rights are "poorly defined and protected by law", a country gets a value of 1 and if property rights are "clearly defined and well protected by law", a country gets a measure of 7 . The variable from Fraser Institute varies from 0 to 10 where 10 indicates a higher protection of property rights. 


\subsection{Freedom to own foreign currency bank accounts.}

The indicator originates from International Monetary Fund and taps on individual liberties. The Fraser Institute's version of the indicator varies from 0 to 10 , where a country scores 10 if ownership of foreign currency bank accounts is permitted without restrictions, and 0 if otherwise.

\subsection{Tariffs on foreign trade index}

The index captures the extent to which businesses face barriers when trading internationally. It consists of the following indicators:

- Revenues from trade taxes, which originates from International Monetary Fund and is measured by the amount of tax on international trade as a shareof exports and imports. Countries with higher taxes on trade receive lower scores, while countries with no taxes on international trade receive 10 .

- Mean tariff rate, which originates from the World Trade Organizaiton. Countries that do not impose tariffs receive a score of 10 . The higher the mean tariff rate, the lower the score.

- Standard deviation of tariff rates, which comes from the World Trade Organization. Countries that impose uniform tariff rates are assigned a score of 10 , while countries with higher standard deviation of tariff rates receive a lower score.

\subsection{Capital controls}

The indicator originates from the International Monetary Fund and measures the percentage of "capital controls not levied as a share of the total number of capital controls listed", multiplied by 10 . Higher values indicates lower amount of capital controls. Capital controls are government measures to restrict the flow of foreign capital in and out of the domestic economy, including taxes, tariffs, restriction on volumes, legislation, etc.

\subsection{Credit market regulations index}

The index measures to what extent government regulates the credit market. It consists of the following indicators:

- Ownership of banks by the government that originates from Aginer et al (2019) and Barth, Capiro and Levine (2006). The variable reflects the percentage of bank deposits 
held in privately owned banks, where higher values correspond to higher percentage of private banks.

- Private sector credit originates from the World Development Indicators. The indicator measures "the extent of government borrowing relative to private sector borrowing." Larger loans by the government imply more central planning and correspond to lower values in the indicator. Higher values correspond to higher share of credit to the private sector.

- Interest rate controls originate from the World Development Indicators and measure the degree to which interest rates are determined by the market, whether monetary policy is stable and whether the real-deposit and lending rates are reasonable. Countries where interest rates are determined primarily by the market, when they are positive and when deposit and lending-rates are reasonable, they received a score of 10. Countries, where the deposit and lending rates are fixed by the government, while interest rates are negative, received a score of 0 .

\section{Social-liberal features}

In the calculation of social-liberal features indices, we use selected individual questions from the V-Dem dataset, pertaining to egalitarian features. The description of the indicators are copied from the V-Dem Codebook (Coppedge, Gerring, Knutsen, Lindberg, Teorell, Altman, Bernhard, Fish, Glynn, Hicken, Lührmann, Marquardt, McMann, Paxton, Pemstein, Seim, Sigman, Skaaning, Staton, Cornell, et al., 2020).

\subsection{Equality in access to healthcare (v2pehealth)}

Question: To what extent is high quality basic healthcare guaranteed to all, sufficient to enable them to exercise their basic political rights as adult citizens?

Clarification: Poor-quality healthcare can make citizens unable to exercise their basic rights as adult citizens by failing to adequately treat preventable and treatable illnesses that render them unable to work, participate in social or political organizations, or vote (where voting is allowed).

Responses:

0: Extreme. Because of poor-quality healthcare, at least 75 percent (\%) of citizens' ability to exercise their political rights as adult citizens is undermined.

1: Unequal. Because of poor-quality healthcare, at least 25 percent (\%) of citizens' ability to exercise their political rights as adult citizens is undermined. 
2: Somewhat equal. Because of poor-quality healthcare, ten to 25 percent (\%) of citizens' ability to exercise their political rights as adult citizens is undermined.

3: Relatively equal. Basic health care is overall equal in quality but because of poor-quality healthcare, five to ten percent $(\%)$ of citizens' ability to exercise their political rights as adult citizens is undermined.

4: Equal. Basic health care is equal in quality and less than five percent $(\%)$ of citizens cannot exercise their basic political rights as adult citizens.

\subsection{Equality in access to education (v2peedueq)}

Question: To what extent is high quality basic education guaranteed to all, sufficient to enable them to exercise their basic rights as adult citizens?

Clarification: Basic education refers to ages typically between 6 and 16 years of age but this varies slightly among countries.

\section{Responses:}

0: Extreme. Provision of high quality basic education is extremely unequal and at least 75 percent $(\%)$ of children receive such low-quality education that undermines their ability to exercise their basic rights as adult citizens.

1: Unequal. Provision of high quality basic education is extremely unequal and at least 25 percent $(\%)$ of children receive such low-quality education that undermines their ability to exercise their basic rights as adult citizens.

2: Somewhat equal. Basic education is relatively equal in quality but ten to 25 percent (\%) of children receive such low-quality education that undermines their ability to exercise their basic rights as adult citizens.

3: Relatively equal. Basic education is overall equal in quality but five to ten percent (\%) of children receive such low-quality education that probably undermines their ability to exercise their basic rights as adult citizens.

4: Equal. Basic education is equal in quality and less than five percent (\%) of children receive such low-quality education that probably undermines their ability to exercise their basic rights as adult citizens. 


\subsection{Means-tested v. universalistic policy (v2dlunivl)}

Question: How many welfare programs are means-tested and how many benefit all (or virtually all) members of the polity?

Clarification: A means-tested program targets poor, needy, or otherwise underprivileged constituents. Cash-transfer programs are normally means-tested. A universal (non-means tested) program potentially benefits everyone. This includes free education, national health care schemes, and retirement programs. Granted, some may benefit more than others from these programs (e.g., when people with higher salaries get higher unemployment benefits). The key point is that practically everyone is a beneficiary, or potential beneficiary. The purpose of this question is not to gauge the size of the welfare state but rather its quality. So, your answer should be based on whatever programs exist.

\section{Responses:}

0: There are no, or extremely limited, welfare state policies (education, health, retirement, unemployment, poverty programs).

1: Almost all of the welfare state policies are means-tested.

2: Most welfare state policies means-tested, but a significant portion (e.g. $1 / 4$ or $1 / 3$ ) is universalistic and potentially benefits everyone in the population.

3: The welfare state policies are roughly evenly divided between means-tested and universalistic.

4: Most welfare state policies are universalistic, but a significant portion (e.g., 1/4 or 1/3) are means-tested.

5: Almost all welfare state policies are universal in character. Only a small portion is meanstested.

\subsection{Particularistic or public goods (v2dlencmps)}

Question: Considering the profile of social and infrastructural spending in the national

budget, how "particularistic" or "public goods" are most expenditures?

Clarification: Particularistic spending is narrowly targeted on a specific corporation, sector, social group, region, party, or set of constituents. Such spending may be referred to as "pork", "clientelistic", or "private goods." Public-goods spending is intended to benefit all communities within a society, though it may be means-tested so as to target poor, needy, or otherwise 
underprivileged constituents. The key point is that all who satisfy the means-test are allowed to receive the benefit. Your answer should consider the entire budget of social and infrastructural spending. We are interested in the relative value of particularistic and public-goods spending, not the number of bills or programs that fall into either category.

Responses:

0: Almost all of the social and infrastructure expenditures are particularistic.

1: Most social and infrastructure expenditures are particularistic, but a significant portion (e.g. 1/4 or $1 / 3)$ is public-goods.

2: Social and infrastructure expenditures are evenly divided between particularistic and publicgoods programs.

3: Most social and infrastructure expenditures are public-goods but a significant portion (e.g., 1/4 or $1 / 3)$ is particularistic.

4: Almost all social and infrastructure expenditures are public-goods in character. Only a small portion is particularistic.

\section{Deliberative features}

In the calculation of deliberative features index, we use selected individual questions from the VDem dataset, pertaining to deliberation and civil society participation. The description of the indicators are copied from the V-Dem Codebook (Coppedge, Gerring, Knutsen, Lindberg, Teorell, Altman, Bernhard, Fish, Glynn, Hicken, Lührmann, Marquardt, McMann, Paxton, Pemstein, Seim, Sigman, Skaaning, Staton, Cornell, et al., 2020).

\subsection{Engaged society, V-Dem (v2dlengage)}

Question: When important policy changes are being considered, how wide and how independent are public deliberations?

Clarification: This question refers to deliberation as manifested in discussion, debate, and other public forums such as popular media.

Responses:

0: Public deliberation is never, or almost never allowed. 
1: Some limited public deliberations are allowed but the public below the elite levels is almost always either unaware of major policy debates or unable to take part in them.

2: Public deliberation is not repressed but nevertheless infrequent and non-elite actors are typically controlled and/or constrained by the elites.

3: Public deliberation is actively encouraged and some autonomous non-elite groups participate, but it is confined to a small slice of specialized groups that tends to be the same across issueareas.

4: Public deliberation is actively encouraged and a relatively broad segment of non-elite groups often participate and vary with different issue-areas.

5: Large numbers of non-elite groups as well as ordinary people tend to discuss major policies among themselves, in the media, in associations or neighborhoods, or in the streets. Grass-roots deliberation is common and unconstrained.

\subsection{Respect counterarguments (v2dlcountr)}

Question: When important policy changes are being considered, to what extent do political elites acknowledge and respect counterarguments?

Clarification: Because discourse varies greatly from person to person, base your answer on the style that is most typical of prominent national political leaders.

Responses:

0: Counterarguments are not allowed or if articulated, punished.

1: Counterarguments are allowed at least from some parties, but almost always are ignored.

2: Elites tend to acknowledge counterarguments but then explicitly degrade them by making a negative statement about them or the individuals and groups that propose them.

3: Elites tend to acknowledge counterarguments without making explicit negative or positive statements about them.

4: Elites almost always acknowledge counterarguments and explicitly value them, even if they ultimately reject them for the most part.

5: Elites almost always acknowledge counterarguments and explicitly value them, and frequently also even accept them and change their position. 


\subsection{CSO consultation (v2cscnsult)}

Question: Are major civil society organizations (CSOs) routinely consulted by policymakers on policies relevant to their members?

Responses:

0: No. There is a high degree of insulation of the government from CSO input. The government may sometimes enlist or mobilize CSOs after policies are adopted to sell them to the public at large. But it does not often consult with them in formulating policies.

1: To some degree. CSOs are but one set of voices that policymakers sometimes take into account.

2: Yes. Important CSOs are recognized as stakeholders in important policy areas and given voice on such issues. This can be accomplished through formal corporatist arrangements or through less formal arrangements.

\subsection{Range of consultation (v2dlconslt)}

Question: When important policy changes are being considered, how wide is the range of consultation at elite levels?

Responses:

0: No consultation. The leader or a very small group (e.g. military council) makes authoritative decisions on their own.

1: Very little and narrow. Consultation with only a narrow circle of loyal party/ruling elites.

2: Consultation includes the former plus a larger group that is loyal to the government, such as the ruling party's or parties' local executives and/or women, youth and other branches.

3: Consultation includes the former plus leaders of other parties.

4: Consultation includes the former plus a select range of society/labor/business representatives.

5: Consultation engages elites from essentially all parts of the political spectrum and all politically relevant sectors of society and business. 


\section{Appendix B. Correlation between the variables in different samples}

Table B.1 Correlations in the sample, where $\mathrm{CO}_{2} / \mathrm{GDP}$ is the dependent variable

\begin{tabular}{|c|c|c|c|c|c|c|c|}
\hline & $\begin{array}{l}\text { Elect. } \\
\text { dem. }\end{array}$ & $\begin{array}{l}\text { Thin liberal } \\
\text { features }\end{array}$ & $\begin{array}{l}\text { Delib. } \\
\text { features }\end{array}$ & $\begin{array}{l}\text { Soc-liberal } \\
\text { features }\end{array}$ & $\begin{array}{l}\text { GDP/cap. } \\
(\mathrm{ln})\end{array}$ & $\begin{array}{l}\text { Trade } \\
\text { open. }(\ln )\end{array}$ & $\begin{array}{l}\text { Corrupt } \\
\text { ion }\end{array}$ \\
\hline Elect.dem. & 1.00 & & & & & & \\
\hline Thin liberal features & 0.53 & 1.00 & & & & & \\
\hline Deliberative features & 0.79 & 0.42 & 1.00 & & & & \\
\hline Social-liberal features & 0.62 & 0.52 & 0.51 & 1.00 & & & \\
\hline GDP per capita (ln) & 0.64 & 0.63 & 0.51 & 0.81 & 1.00 & & \\
\hline Trade openness (ln) & 0.07 & 0.25 & 0.05 & 0.33 & 0.29 & 1.00 & \\
\hline Corruption & -0.71 & -0.55 & -0.63 & -0.80 & -0.79 & -0.23 & 1.00 \\
\hline
\end{tabular}

Table B.2 Correlations in the sample, where EPS is the dependent variable

\begin{tabular}{|c|c|c|c|c|c|c|c|}
\hline & $\begin{array}{l}\text { Elect. } \\
\text { dem. }\end{array}$ & $\begin{array}{l}\text { Thin liberal } \\
\text { features }\end{array}$ & $\begin{array}{l}\text { Delib. } \\
\text { features }\end{array}$ & $\begin{array}{l}\text { Soc-liberal } \\
\text { features }\end{array}$ & $\begin{array}{l}\text { GDP/cap. } \\
\text { (ln) }\end{array}$ & $\begin{array}{l}\text { Trade open. } \\
(\ln )\end{array}$ & $\begin{array}{l}\text { Corrupt } \\
\text { ion }\end{array}$ \\
\hline Electoral democracy & 1.00 & & & & & & \\
\hline Thin liberal features & 0.58 & 1.00 & & & & & \\
\hline Deliberative features & 0.74 & 0.51 & 1.00 & & & & \\
\hline Social-liberal features & 0.65 & 0.72 & 0.50 & 1.00 & & & \\
\hline GDP per capita (ln) & 0.65 & 0.87 & 0.58 & 0.81 & 1.00 & & \\
\hline Trade openness (ln) & 0.20 & 0.35 & 0.08 & 0.37 & 0.30 & 1.00 & \\
\hline Corruption & -0.70 & -0.72 & -0.67 & -0.74 & -0.79 & -0.24 & 1.00 \\
\hline
\end{tabular}

Table B.3 Correlations in the sample, where environmental efforts is the dependent variable

\begin{tabular}{|c|c|c|c|c|c|c|c|}
\hline & $\begin{array}{l}\text { Elect. } \\
\text { dem. }\end{array}$ & $\begin{array}{l}\text { Thin liberal } \\
\text { features }\end{array}$ & $\begin{array}{l}\text { Delib. } \\
\text { features }\end{array}$ & $\begin{array}{l}\text { Soc-liberal } \\
\text { features }\end{array}$ & $\begin{array}{l}\text { GDP/cap. } \\
\text { (ln) }\end{array}$ & $\begin{array}{l}\text { Trade } \\
\text { open. (ln) }\end{array}$ & $\begin{array}{l}\text { Corrupti } \\
\text { on }\end{array}$ \\
\hline Electoral democracy & 1.00 & & & & & & \\
\hline Thin liberal features & 0.31 & 1.00 & & & & & \\
\hline Deliberative features & 0.77 & 0.20 & 1.00 & & & & \\
\hline Social-liberal features & 0.31 & 0.43 & 0.25 & 1.00 & & & \\
\hline GDP per capita (ln) & 0.25 & 0.51 & 0.08 & 0.68 & 1.00 & & \\
\hline Trade openness (ln) & 0.10 & 0.37 & 0.11 & 0.42 & 0.34 & 1.00 & \\
\hline Corruption & -0.49 & -0.37 & -0.45 & -0.64 & -0.55 & -0.28 & 1.00 \\
\hline
\end{tabular}




\section{Appendix C. Country rankings for different cross-country samples}

Table C.1. Country rankings on thin liberal, deliberative and social-liberal democracy for the sample of OECD democracies

\begin{tabular}{rlll}
\hline N & Thin Liberal democracy & Social-liberal democracy & Deliberative democracy \\
\hline 1 & Germany, West & Norway & Norway \\
2 & Netherlands & Spain & Germany, West \\
3 & United Kingdom & Czech Republic & Germany \\
4 & Denmark & Japan & Switzerland \\
5 & Switzerland & Sweden & Denmark \\
6 & Belgium & Belgium & Sweden \\
7 & Canada & Switzerland & Finland \\
8 & Ireland & Denmark & Italy \\
9 & United States & France & Netherlands \\
10 & Italy & Germany, West & United States \\
11 & Sweden & Greece & Indonesia \\
12 & Finland & Germany & Austria \\
13 & France & Korea, South & Belgium \\
14 & Germany & Finland & Australia \\
15 & Norway & Austria & Portugal \\
16 & Japan & Slovenia & Brazil \\
17 & Austria & Canada & Canada \\
18 & Australia & Australia & Korea, South \\
19 & Spain & Italy & India \\
20 & Portugal & Netherlands & Spain \\
21 & Czech Republic & Portugal & Slovenia \\
22 & Slovenia & United Kingdom & Japan \\
23 & Slovakia & Ireland & United Kingdom \\
24 & Greece & Poland & France \\
25 & Korea, South & Hungary & Greece \\
26 & Hungary & Slovakia & Czech Republic \\
27 & Indonesia & Turkey & Poland \\
28 & Turkey & United States & Ireland \\
29 & Poland & Brazil & Slovakia \\
30 & Brazil & Indonesia & Hungary \\
31 & India & & Turkey \\
\hline
\end{tabular}


Table C.2. Country rankings on thin liberal, deliberative and social-liberal democracy for the sample of democracies in the developing world

\begin{tabular}{|c|c|c|c|}
\hline $\mathbf{N}$ & Thin liberal democracy & Social-liberal democracy & Deliberative democracy \\
\hline 1 & Panama & Czech Republic & Tunisia \\
\hline 2 & Guatemala & Korea, South & Mauritius \\
\hline 3 & Peru & Estonia & Costa Rica \\
\hline 4 & Armenia & Lithuania & Uruguay \\
\hline 5 & Georgia & Slovenia & Indonesia \\
\hline 6 & Romania & Bhutan & Mongolia \\
\hline 7 & Bulgaria & Costa Rica & Estonia \\
\hline 8 & Latvia & Mauritius & Ghana \\
\hline 9 & Estonia & Poland & Chile \\
\hline 10 & Uruguay & Uruguay & Brazil \\
\hline 11 & Chile & Croatia & Kenya \\
\hline 12 & Mauritius & Latvia & Korea, South \\
\hline 13 & Zambia & Armenia & Slovenia \\
\hline 14 & Nicaragua & Malaysia & Niger \\
\hline 15 & Slovakia & Georgia & Benin \\
\hline 16 & Lithuania & Slovakia & Senegal \\
\hline 17 & Costa Rica & Romania & Lithuania \\
\hline 18 & El Salvador & Bulgaria & Thailand \\
\hline 19 & Mongolia & Ukraine & Bulgaria \\
\hline 20 & Paraguay & North Macedonia & Czech Republic \\
\hline 21 & Czech Republic & Lesotho & Jamaica \\
\hline 22 & Korea, South & Hungary & Philippines \\
\hline 23 & Liberia & Botswana & Bhutan \\
\hline 24 & Hungary & Serbia & Sierra Leone \\
\hline 25 & Albania & Sri Lanka & Panama \\
\hline 26 & Botswana & Argentina & India \\
\hline 27 & Slovenia & Moldova & Latvia \\
\hline 28 & Honduras & Jamaica & Botswana \\
\hline 29 & Dominican Republic & Mongolia & Mali \\
\hline 30 & Bolivia & Panama & Slovakia \\
\hline 31 & Kyrgyzstan & Turkey & Pakistan \\
\hline 32 & Croatia & Albania & Dominican Republic \\
\hline 33 & Nigeria & Ecuador & Peru \\
\hline 34 & Kenya & Kyrgyzstan & Poland \\
\hline 35 & Jamaica & Thailand & Malawi \\
\hline 36 & Papua New Guinea & Tunisia & Mauritania \\
\hline 37 & Poland & Ghana & Colombia \\
\hline 38 & Philippines & Senegal & Nepal \\
\hline
\end{tabular}




\begin{tabular}{|c|c|c|c|}
\hline $\mathbf{N}$ & Thin liberal democracy & Social-liberal democracy & Deliberative democracy \\
\hline 39 & Indonesia & Chile & Mexico \\
\hline 40 & North Macedonia & Benin & Bolivia \\
\hline 41 & Turkey & Colombia & Nigeria \\
\hline 42 & Ghana & Brazil & Georgia \\
\hline 43 & Brazil & Kenya & Serbia \\
\hline 44 & Moldova & Nicaragua & Honduras \\
\hline 45 & Ecuador & Venezuela & Argentina \\
\hline 46 & Madagascar & Burundi & Ukraine \\
\hline 47 & Mexico & Indonesia & Croatia \\
\hline 48 & Serbia & Mali & Lesotho \\
\hline 49 & Colombia & Sierra Leone & Liberia \\
\hline 50 & Malaysia & Bolivia & Kyrgyzstan \\
\hline 51 & Lesotho & Peru & Zambia \\
\hline 52 & Mauritania & Niger & Paraguay \\
\hline 53 & Guinea & Nepal & Romania \\
\hline 54 & Argentina & Mexico & Moldova \\
\hline 55 & Thailand & India & Malaysia \\
\hline 56 & Sierra Leone & Philippines & El Salvador \\
\hline 57 & Malawi & Zambia & Turkey \\
\hline 58 & Ukraine & Mauritania & Guatemala \\
\hline 59 & Bhutan & Malawi & Ecuador \\
\hline 60 & Mali & Dominican Republic & Albania \\
\hline 61 & Senegal & Nigeria & Hungary \\
\hline 62 & Bangladesh & Liberia & Guinea \\
\hline 63 & Tunisia & Guatemala & Madagascar \\
\hline 64 & Sri Lanka & El Salvador & Nicaragua \\
\hline 65 & Venezuela & Guinea & Papua New Guinea \\
\hline 66 & Pakistan & Paraguay & Armenia \\
\hline 67 & Benin & Bangladesh & Burundi \\
\hline 68 & Burundi & Papua New Guinea & Sri Lanka \\
\hline 69 & Nepal & Honduras & North Macedonia \\
\hline 70 & India & Madagascar & Venezuela \\
\hline 71 & Niger & Pakistan & Bangladesh \\
\hline
\end{tabular}




\section{Appendix D. Comparing democracies with thin liberal, social-liberal, and deliberative features with authoritarian regimes}

In this additional analysis, we create the indices of thin liberal, social-liberal and deliberative democracy to compare their environmental commitment to those in authoritarian regimes. To create indices of democracy with the respective features, we multiply the thin-liberal, social-liberal, and deliberative indices with a democracy dummy taken from Bjørnskov and Rode (2020), which is an extended version of the dichotomous measure of democracy from Cheibub, Gandhi and Vreeland (2010). We do not multiply the measure of the three features with the continuous electoral democracy index to reduce the variation brought by the variation in the level of electoral democracy, leaving only the variation in the three features between democracies and authoritarian regimes that are coded as 0. Figure D.1. presents the logic of our operationalization, while Figure D.1. presents the results.

Table D.1. Strategy for operationalization of different democratic traditions

\begin{tabular}{|c|c|}
\hline Political system & Operationalization \\
\hline Electoral democracy (model 1) & Electoral Democracy Index (v2x_polyarchy) \\
\hline \multirow[t]{8}{*}{ Thin liberal democracy (model 2) } & Dichotomous Democracy Index * \\
\hline & Thin Liberal Features Factor \\
\hline & (Size of government; \\
\hline & Protection of property rights; \\
\hline & Freedom to own foreign currency bank accounts; \\
\hline & Tariffs on foreign trade; \\
\hline & Capital controls; \\
\hline & Credit market regulations) \\
\hline \multirow[t]{6}{*}{ Social-liberal democracy (model 3) } & Dichotomous Democracy Index * \\
\hline & Socio-Liberal Features Factor \\
\hline & (Health equality; \\
\hline & Educational equality; \\
\hline & Spending for public goods; \\
\hline & Universalistic character of policies) \\
\hline \multirow[t]{6}{*}{ Deliberative democracy (model 4) } & Dichotomous Democracy Index * \\
\hline & Deliberative Features Factor \\
\hline & (Extent of public deliberations; \\
\hline & Officials' respect for counterarguments; \\
\hline & Extent of civil society consultation \\
\hline & Range of consultations) \\
\hline Reference: Authoritarian system & Dichotomous Democracy Index $=0$ \\
\hline
\end{tabular}


Table D.2. The relationship between thin liberal, social-liberal, and deliberative features of democracies and the effectiveness of climate laws

\begin{tabular}{lllll}
\hline & Model 1 & Model 2 & Model 3 & Model 4 \\
DV: $\ln \left(\mathrm{CO}_{2} / \mathrm{GDP}\right)$ & & & \\
\hline
\end{tabular}

$\begin{array}{lc}\text { Electoral democracy } & 0.008 \\ & (0.106) \\ \text { Stock of laws*Electoral democracy } & -0.031 \dagger \\ & (0.016)\end{array}$

Thin liberal democracy

0.003

Stock of laws*'Thin liberal democracy

$-0.005^{*}$

$(0.002)$

Social-liberal democracy

0.017

(0.014)

$-0.005^{*}$

Stock of laws*Social-liberal democracy

(0.002)

Deliberative democracy

\begin{tabular}{cccc} 
& & & 0.006 \\
& & & $(0.011)$ \\
& & & $-0.004 \dagger$ \\
& & & $(0.002)$ \\
0.014 & 0.008 & 0.008 & 0.003 \\
$(0.012)$ & $(0.008)$ & $(0.007)$ & $(0.008)$ \\
$-8.908^{*}$ & $-8.799 *$ & $-8.677^{*}$ & $-9.056^{*}$ \\
$(3.615)$ & $(3.603)$ & $(3.622)$ & $(3.576)$ \\
& & & \\
2,074 & 2,074 & 2,074 & 2,074 \\
0.314 & 0.315 & 0.317 & 0.313 \\
126 & 126 & 126 & 126 \\
yes & yes & yes & yes \\
\hline
\end{tabular}

\begin{tabular}{lcccc} 
Observations & 2,074 & 2,074 & 2,074 & 2,074 \\
$\mathrm{R}^{2}$ & 0.314 & 0.315 & $\mathbf{0 . 3 1 7}$ & 0.313 \\
Number of countries & 126 & 126 & 126 & 126 \\
Year fixed effects & yes & yes & yes & yes \\
\hline OLS regression of a natural logarithm of $\mathrm{CO}_{2}$ emissions per 2011 PPP $\$ 1$ GDP on the interaction \\
effect between the stock of recent mitigation laws and different democracy features, with country and \\
year fixed effects. The regressions control for the GDP HP filter, squared term of GDP per capita \\
(natural log), the size of imports and services as a percentage of GDP, difference between the yearly \\
average temperature and the long term (1980-2015) average temperature and federalism. Robust \\
standard errors in parentheses, *** $\mathrm{p}<0.001, * * \mathrm{p}<0.01, * \mathrm{p}<0.05, \dagger \mathrm{p}<0.1$. All independent variables \\
are lagged 1 year.
\end{tabular}


1) Conditional marginal effect of $N$ Laws

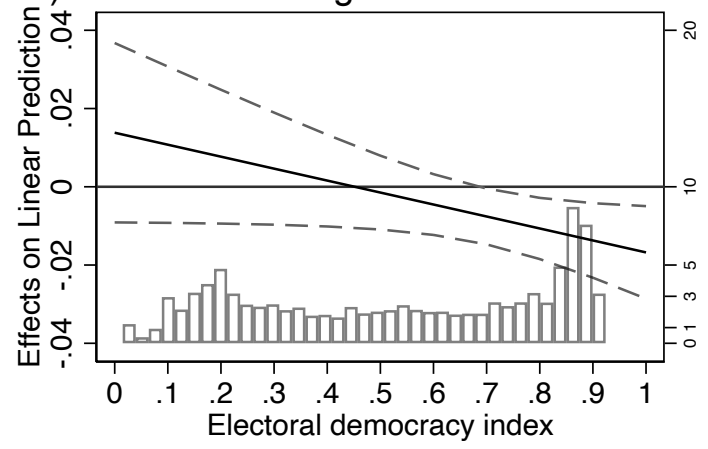

3) Conditional marginal effect of $\mathrm{N}$ Laws

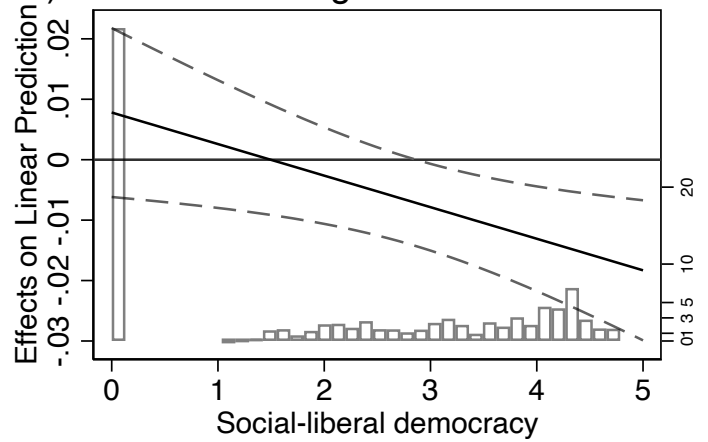

2) Conditional marginal effect of $\mathrm{N}$ Laws

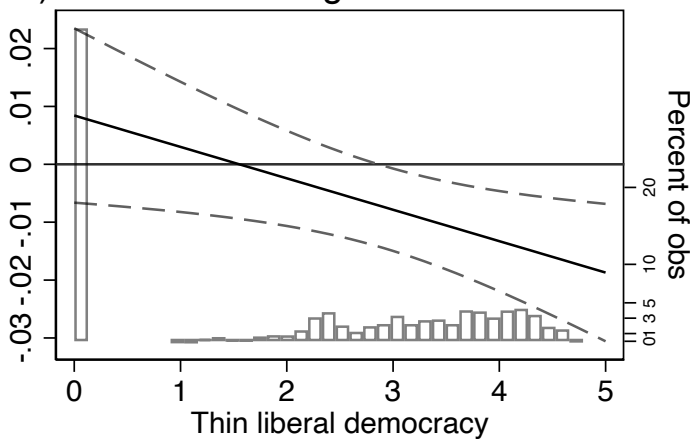

4) Conditional marginal effect of $N$ Laws

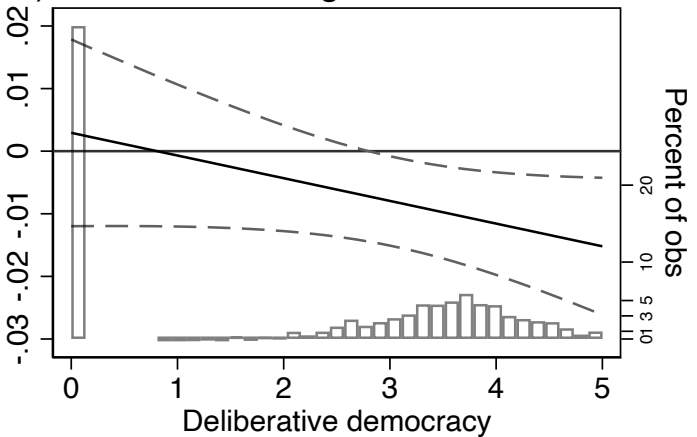

Figure D.1. Marginal effects of the stock of recent climate change mitigation laws on $\mathrm{CO}_{2}$ emissions conditional on the level of electoral democracy (1), extent of thin liberal democracy features (2), social-liberal democracy features (3), and deliberative democracy features (4), with $95 \%$ confidence intervals. 
Table D.2. The relationship between thin liberal, social-liberal, and deliberative features of democracies and environmental policy stringency in OECD and BRIICS.

\begin{tabular}{|c|c|c|c|c|c|}
\hline DV: EPS & Model 1 & Model 2 & Model 3 & Model 4 & Model 5 \\
\hline Between part: & & & & & \\
\hline Electoral democracy & $\begin{array}{c}0.170 \\
(0.425)\end{array}$ & & & & \\
\hline Thin liberal democracy & & $\begin{array}{l}0.118 \dagger \\
(0.061)\end{array}$ & & & $\begin{array}{l}-0.099 \\
(0.137)\end{array}$ \\
\hline Social-liberal democracy & & & $\begin{array}{c}0.157^{* *} \\
(0.054)\end{array}$ & & $\begin{array}{c}0.274^{* *} \\
(0.094)\end{array}$ \\
\hline Deliberative democracy & & & & $\begin{array}{c}0.095 \\
(0.066)\end{array}$ & $\begin{array}{l}-0.049 \\
(0.111)\end{array}$ \\
\hline GDP per capita (ln) & $\begin{array}{c}0.004 \\
(0.004)\end{array}$ & $\begin{array}{c}0.003 \\
(0.004)\end{array}$ & $\begin{array}{c}0.003 \\
(0.004)\end{array}$ & $\begin{array}{c}0.002 \\
(0.004)\end{array}$ & $\begin{array}{c}0.004 \\
(0.005)\end{array}$ \\
\hline Trade openness & $\begin{array}{c}1.640 \\
(2.550)\end{array}$ & $\begin{array}{c}1.335 \\
(2.442)\end{array}$ & $\begin{array}{c}0.896 \\
(2.346)\end{array}$ & $\begin{array}{c}1.328 \\
(2.361)\end{array}$ & $\begin{array}{c}0.081 \\
(2.258)\end{array}$ \\
\hline Time in the EU & $\begin{array}{l}0.006 \dagger \\
(0.004)\end{array}$ & $\begin{array}{c}0.005 \\
(0.003)\end{array}$ & $\begin{array}{l}0.006 \dagger \\
(0.003)\end{array}$ & $\begin{array}{l}0.006 \dagger \\
(0.003)\end{array}$ & $\begin{array}{l}0.006 \dagger \\
(0.003)\end{array}$ \\
\hline Corruption & $\begin{array}{c}-1.660 * * * \\
(0.428)\end{array}$ & $\begin{array}{c}-1.378^{* * *} \\
(0.350)\end{array}$ & $\begin{array}{c}-1.142^{* *} \\
(0.373)\end{array}$ & $\begin{array}{c}-1.498^{* * *} \\
(0.372)\end{array}$ & $\begin{array}{c}-1.099 * * * \\
(0.332)\end{array}$ \\
\hline
\end{tabular}

Within part:

\begin{tabular}{ll}
\hline Electoral democracy & -0.827 \\
& $(0.673)$
\end{tabular}

Thin liberal democracy

$-0.119$

0.054

(0.109)

$(0.135)$

Social-liberal democracy

$-0.229$

0.415

(0.149)

(0.295)

Deliberative democracy

$(0.149)$

$-0.302 * *$

$-0.545^{* *}$

GDP per capita (ln)

$0.037^{*}$

$0.038^{*}$

$0.040 *$

(0.105)

(0.198)

(0.016)

(0.016)

(0.016)

$0.032 *$

$0.031 \dagger$

(0.016) (0.017)

Trade openness

2.188

3.306

1.758

$-0.085$

(5.370)

(5.192)

(5.334)

0.276

(5.253)

Time in the EU

0.016

0.016

0.017

(5.501)

(0.014)

0.014

0.013

(0.014)

(0.013)

$-1.764$

$(0.013)$

(0.012)

Corruption

$-1.656$

$-1.437$

(1.454)

$-3.098^{* *}$

$-3.135^{* *}$

Constant

$1.018^{*}$

(1.447)

$0.596^{*}$

(1.190)

(1.077)

$0.773^{* *}$

(0.279)

$0.802^{* *}$

$0.613^{*}$

(0.422)

(0.236)

(0.274)

(0.239)

\begin{tabular}{lccccc} 
Observations & 753 & 753 & 753 & 753 & 753 \\
$\mathrm{R}^{2}$ between & 0.695 & 0.714 & $\mathbf{0 . 7 3 8}$ & 0.708 & 0.746 \\
$\mathrm{R}^{2}$ within & 0.780 & 0.780 & 0.781 & $\mathbf{0 . 7 9 1}$ & 0.796 \\
Number of countries & 34 & 34 & 34 & 34 & 34 \\
Year fixed effects & yes & yes & yes & yes & yes \\
\hline
\end{tabular}

Within-between regression of environmental policy stringency on different democracy features with year fixed effects in the OECD and BRIICS. Both within- and between-parts of the equation include controls for the GDP per capita (natural $\log$ ), trade openness, time in the EU, and corruption. Robust standard errors in parentheses, $* * * \mathrm{p}<0.001, * * \mathrm{p}<0.01, * \mathrm{p}<0.05, \uparrow \mathrm{p}<0.1$. All independent variables are lagged 1 year. 
Table D.3. The relationship between thin liberal, social-liberal, and deliberative features of democracies and environmental efforts in developing countries.

\begin{tabular}{|c|c|c|c|c|c|}
\hline DV: Environmental efforts & Model 1 & Model 2 & Model 3 & Model 4 & Model 5 \\
\hline Between part: & & & & & \\
\hline Electoral democracy & $\begin{array}{c}2.449 * * * \\
(0.407)\end{array}$ & & & & \\
\hline Thin liberal democracy & & $\begin{array}{c}0.267^{* * *} \\
(0.058)\end{array}$ & & & $\begin{array}{c}0.063 \\
(0.149)\end{array}$ \\
\hline Social-liberal democracy & & & $\begin{array}{c}0.339 * * * \\
(0.068)\end{array}$ & & $\begin{array}{c}0.384^{* *} \\
(0.142)\end{array}$ \\
\hline Deliberative democracy & & & & $\begin{array}{c}0.264^{* * *} \\
(0.060)\end{array}$ & $\begin{array}{l}-0.106 \\
(0.174)\end{array}$ \\
\hline GDP per capita (ln) & $\begin{array}{c}0.295^{* *} \\
(0.095)\end{array}$ & $\begin{array}{l}0.231 * \\
(0.097)\end{array}$ & $\begin{array}{l}0.235^{*} \\
(0.096)\end{array}$ & $\begin{array}{c}0.263^{* *} \\
(0.098)\end{array}$ & $\begin{array}{l}0.222^{*} \\
(0.101)\end{array}$ \\
\hline Trade openness & $\begin{array}{c}0.494 * * * \\
(0.117)\end{array}$ & $\begin{array}{c}0.461^{* * *} \\
(0.126)\end{array}$ & $\begin{array}{c}0.460^{* * *} \\
(0.129)\end{array}$ & $\begin{array}{c}0.488^{* * *} \\
(0.122)\end{array}$ & $\begin{array}{c}0.448^{* * *} \\
(0.135)\end{array}$ \\
\hline Time in the EU & $\begin{array}{c}-1.955^{* * *} \\
(0.472)\end{array}$ & $\begin{array}{c}-2.561 * * * \\
(0.458)\end{array}$ & $\begin{array}{c}-2.295^{* * *} \\
(0.462)\end{array}$ & $\begin{array}{c}-2.384 * * * \\
(0.459)\end{array}$ & $\begin{array}{c}-2.341 * * * \\
(0.497)\end{array}$ \\
\hline Corruption & $\begin{array}{c}0.170^{* * *} \\
(0.045)\end{array}$ & $\begin{array}{c}0.195^{* * *} \\
(0.045)\end{array}$ & $\begin{array}{c}0.166^{* * *} \\
(0.043)\end{array}$ & $\begin{array}{c}0.211^{* * *} \\
(0.045)\end{array}$ & $\begin{array}{c}0.158^{* * *} \\
(0.044)\end{array}$ \\
\hline
\end{tabular}

Within part:

Electoral democracy $\quad 0.999+$

(0.592)

Thin liberal democracy

0.056

(0.080)

$(0.180)$

Social-liberal democracy

$-0.014-0.148$

$\begin{array}{ll}(0.071) & (0.245)\end{array}$

Deliberative democracy

GDP per capita (ln)

0.626

$(0.452)$

0.008

0.065

(0.077)

$(0.158)$

Trade openness

0.146

(0.450)

0.674

0.673

0.670

Time in the EU

(0.101)

0.159

(0.451)

(0.452)

(0.451)

Time in the EU

$-1.161 \dagger$

(0.108)

0.158

0.160

0.157

$-1.161 \dagger$
$(0.697)$

$-1.689 *$

$(0.108)$

(0.108)

(0.109)

$-1.725^{*}$

$-1.668^{*}$

$-1.681^{*}$

Corruption

$-0.017$

(0.706)

(0.710)

(0.767)

(0.760)

(0.038)

$-0.020$

$-0.021$

$-0.020$

$-0.023$

Constant

$2.311^{* *}$

(0.040)

(0.040)

(0.039)

(0.040)

(0.715)

$3.429 * * *$

$3.372 * * *$

$3.523^{* * *}$

$3.636 * * *$

(0.663)

(0.706)

\begin{tabular}{lccccc} 
Observations & 718 & 718 & 718 & 718 & 718 \\
$\mathrm{R}^{2}$ between & 0.719 & 0.708 & $\mathbf{0 . 7 2 0}$ & 0.706 & 0.721 \\
$\mathrm{R}^{2}$ within & $\mathbf{0 . 0 7 6}$ & 0.068 & 0.068 & 0.068 & 0.070 \\
Number of countries & 115 & 115 & 115 & 115 & 115 \\
Year fixed effects & yes & yes & yes & yes & yes \\
\hline
\end{tabular}

Within-between regression of 'environmental efforts' in the developing world on different democracy features, with year fixed effects. Both within- and between-parts of the equation include controls for the GDP per capita (natural $\log$ ), trade openness, time in the EU, and corruption. Robust standard errors in parentheses, ${ }^{* * *} \mathrm{p}<0.001$, $* * \mathrm{p}<0.01, * \mathrm{p}<0.05, \dagger \mathrm{p}<0.1$. All independent variables are lagged 1 year. 


\section{Appendix E. Comparing the effects of thin liberal, social liberal, and deliberative features without distinguishing between the regime types}

In this section we perform the same set of regressions as in the main analysis, but for the full sample of countries without distinguishing them into regime type. Thereby, we investigate whether the prevalence of thin liberal, social-liberal, and deliberative features plays a role in environmental commitment of countries. In all models we additionally control for the level of electoral democracy, as it might influence both our independent and dependent variables.

Table E.1. The relationship between thin liberal, social-liberal, and deliberative features and effectiveness of climate laws

\begin{tabular}{|c|c|c|c|c|}
\hline DV: $\ln \left(\mathrm{CO}_{2} / \mathrm{GDP}\right)$ & Model 1 & Model 2 & Model 3 & Model 4 \\
\hline Stock of laws*Elect.dem. & $\begin{array}{c}-0.031 \dagger \\
(0.016)\end{array}$ & & & \\
\hline Thin liberal features & & $\begin{array}{l}-0.017 \\
(0.026)\end{array}$ & & \\
\hline Stock of laws*Thin liberal & & $\begin{array}{c}-0.011^{*} \\
(0.005)\end{array}$ & & \\
\hline Social-liberal features & & & $\begin{array}{c}0.081 \\
(0.063)\end{array}$ & \\
\hline Stock of laws*Social-liberal & & & $\begin{array}{c}-0.009 * \\
(0.004)\end{array}$ & \\
\hline Deliberative features & & & & $\begin{array}{l}-0.016 \\
(0.026)\end{array}$ \\
\hline Stock of laws*Deliberative & & & & $\begin{array}{l}-0.001 \\
(0.005)\end{array}$ \\
\hline Stock of mitigation laws & $\begin{array}{c}0.014 \\
(0.012)\end{array}$ & $\begin{array}{l}0.030 \dagger \\
(0.018)\end{array}$ & $\begin{array}{l}0.022 \dagger \\
(0.013)\end{array}$ & $\begin{array}{l}-0.005 \\
(0.017)\end{array}$ \\
\hline Electoral democracy & $\begin{array}{c}0.008 \\
(0.106)\end{array}$ & $\begin{array}{l}-0.007 \\
(0.106)\end{array}$ & $\begin{array}{l}-0.029 \\
(0.107)\end{array}$ & $\begin{array}{c}0.026 \\
(0.124)\end{array}$ \\
\hline Constant & $\begin{array}{c}-8.908^{*} \\
(3.615)\end{array}$ & $\begin{array}{c}-9.464^{* *} \\
(3.471)\end{array}$ & $\begin{array}{c}-8.670^{*} \\
(3.562)\end{array}$ & $\begin{array}{c}-9.491 * * \\
(3.503)\end{array}$ \\
\hline Observations & 2,074 & 2,074 & 2,074 & 2,074 \\
\hline $\mathrm{R}^{2}$ & 0.314 & 0.316 & 0.318 & 0.311 \\
\hline Number of countries & 126 & 126 & 126 & 126 \\
\hline Year fixed effects & yes & yes & yes & yes \\
\hline
\end{tabular}


1) Conditional Marginal Effect of $N$ Laws

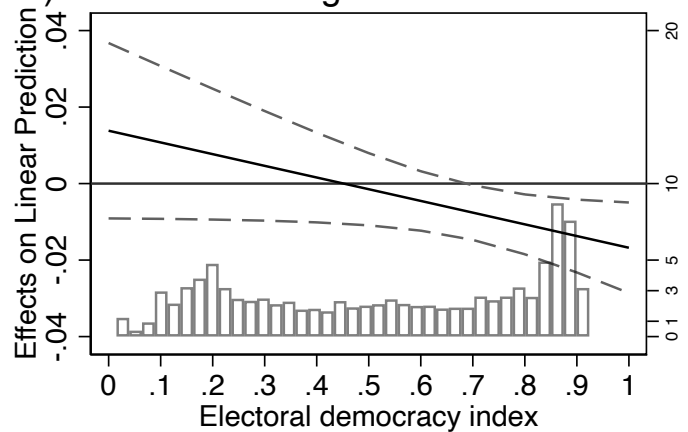

3) Conditional Marginal Effect of $\mathrm{N}$ Laws

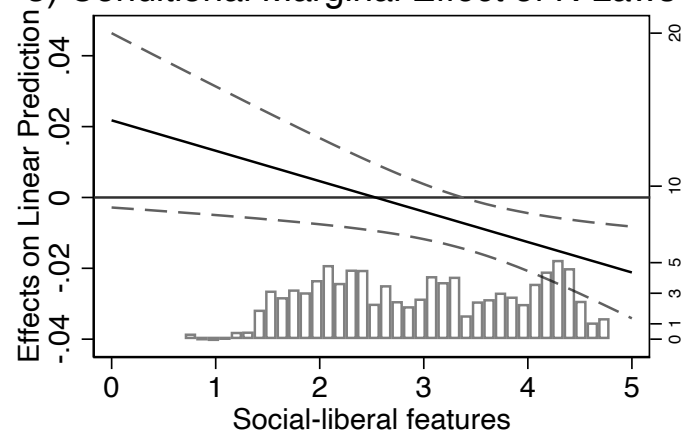

2) Conditional Marginal Effect of $N$ Laws

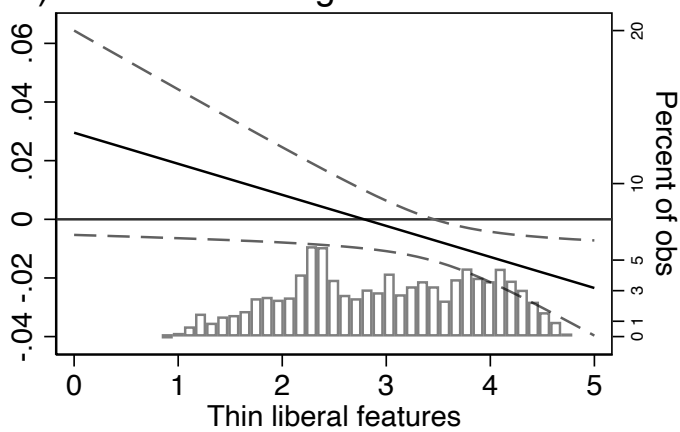

4) Conditional Marginal Effect of N Laws

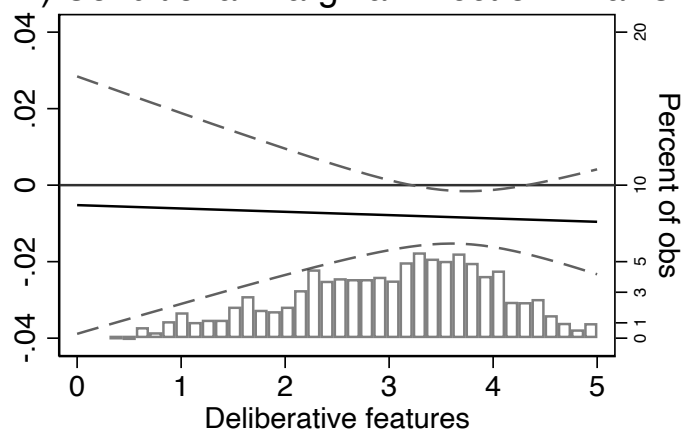

Figure E.1. Marginal effects of the stock of recent climate change mitigation laws on $\mathrm{CO}_{2}$ emissions conditional on the level of electoral democracy (1), extent of thin liberal features (2), social-liberal features (3), and deliberative features (4), with $95 \%$ confidence intervals. 
Table E.2. The relationship between thin liberal, social-liberal and deliberative features and environmental policy stringency in OECD

\begin{tabular}{|c|c|c|c|c|c|}
\hline DV: EPS & Model 1 & Model 2 & Model 3 & Model 4 & Model 5 \\
\hline \multicolumn{6}{|l|}{ Between part: } \\
\hline Thin liberal features & & $\begin{array}{l}0.245 \dagger \\
(0.137)\end{array}$ & & & $\begin{array}{c}0.162 \\
(0.141)\end{array}$ \\
\hline Social-liberal features & & & $\begin{array}{c}0.349 * * * \\
(0.080)\end{array}$ & & $\begin{array}{c}0.366^{* * *} \\
(0.078)\end{array}$ \\
\hline Deliberative features & & & & $\begin{array}{c}0.160 \\
(0.218)\end{array}$ & $\begin{array}{l}0.344 \dagger \\
(0.176)\end{array}$ \\
\hline Electoral democracy & $\begin{array}{c}0.170 \\
(0.425)\end{array}$ & $\begin{array}{c}0.061 \\
(0.417)\end{array}$ & $\begin{array}{l}-0.224 \\
(0.347)\end{array}$ & $\begin{array}{l}-0.087 \\
(0.583)\end{array}$ & $\begin{array}{c}-0.867 \dagger \\
(0.504)\end{array}$ \\
\hline GDP per capita (ln) & $\begin{array}{c}0.004 \\
(0.004)\end{array}$ & $\begin{array}{c}0.000 \\
(0.005)\end{array}$ & $\begin{array}{l}-0.000 \\
(0.004)\end{array}$ & $\begin{array}{c}0.001 \\
(0.006)\end{array}$ & $\begin{array}{l}-0.008 \\
(0.006)\end{array}$ \\
\hline Trade openness & $\begin{array}{c}1.640 \\
(2.550)\end{array}$ & $\begin{array}{c}1.119 \\
(2.502)\end{array}$ & $\begin{array}{c}0.528 \\
(2.278)\end{array}$ & $\begin{array}{c}1.639 \\
(2.154)\end{array}$ & $\begin{array}{c}0.635 \\
(1.878)\end{array}$ \\
\hline Time in the EU & $\begin{array}{l}0.006 \dagger \\
(0.004)\end{array}$ & $\begin{array}{c}0.005 \\
(0.004)\end{array}$ & $\begin{array}{c}0.005 \\
(0.003)\end{array}$ & $\begin{array}{l}0.006 \dagger \\
(0.003)\end{array}$ & $\begin{array}{c}0.003 \\
(0.003)\end{array}$ \\
\hline Corruption & $\begin{array}{c}-1.660^{* * *} \\
(0.428)\end{array}$ & $\begin{array}{c}-1.523^{* * *} \\
(0.345)\end{array}$ & $\begin{array}{c}-1.307 * * * \\
(0.340)\end{array}$ & $\begin{array}{c}-1.619^{* * *} \\
(0.421)\end{array}$ & $\begin{array}{c}-1.162^{* * *} \\
(0.273)\end{array}$ \\
\hline Within part: & & & & & \\
\hline Thin liberal features & & $\begin{array}{l}-0.120 \\
(0.168)\end{array}$ & & & $\begin{array}{l}-0.100 \\
(0.163)\end{array}$ \\
\hline Social-liberal features & & & $\begin{array}{c}0.083 \\
(0.228)\end{array}$ & & $\begin{array}{l}-0.047 \\
(0.223)\end{array}$ \\
\hline Deliberative features & & & & $\begin{array}{c}-0.461 \dagger \\
(0.259)\end{array}$ & $\begin{array}{c}-0.463 \dagger \\
(0.256)\end{array}$ \\
\hline Electoral democracy & $\begin{array}{l}-0.827 \\
(0.673)\end{array}$ & $\begin{array}{l}-0.930 \\
(0.632)\end{array}$ & $\begin{array}{l}-0.919 \\
(0.786)\end{array}$ & $\begin{array}{c}0.367 \\
(1.051)\end{array}$ & $\begin{array}{c}0.321 \\
(1.062)\end{array}$ \\
\hline GDP per capita (ln) & $\begin{array}{l}0.037^{*} \\
(0.016)\end{array}$ & $\begin{array}{l}0.033^{*} \\
(0.016)\end{array}$ & $\begin{array}{l}0.037^{*} \\
(0.016)\end{array}$ & $\begin{array}{l}0.032^{*} \\
(0.015)\end{array}$ & $\begin{array}{l}0.029 \dagger \\
(0.015)\end{array}$ \\
\hline Trade openness & $\begin{array}{c}2.188 \\
(5.370)\end{array}$ & $\begin{array}{c}3.122 \\
(5.372)\end{array}$ & $\begin{array}{c}2.192 \\
(5.455)\end{array}$ & $\begin{array}{c}1.126 \\
(5.315)\end{array}$ & $\begin{array}{c}1.791 \\
(5.355)\end{array}$ \\
\hline Time in the EU & $\begin{array}{c}0.016 \\
(0.014)\end{array}$ & $\begin{array}{c}0.014 \\
(0.013)\end{array}$ & $\begin{array}{c}0.016 \\
(0.013)\end{array}$ & $\begin{array}{c}0.014 \\
(0.013)\end{array}$ & $\begin{array}{c}0.013 \\
(0.013)\end{array}$ \\
\hline Corruption & $\begin{array}{l}-1.656 \\
(1.417)\end{array}$ & $\begin{array}{l}-1.833 \\
(1.416)\end{array}$ & $\begin{array}{l}-1.701 \\
(1.372)\end{array}$ & $\begin{array}{c}-3.090^{*} \\
(1.325)\end{array}$ & $\begin{array}{c}-3.307^{*} \\
(1.289)\end{array}$ \\
\hline Constant & $\begin{array}{l}1.018^{*} \\
(0.422)\end{array}$ & $\begin{array}{c}0.275 \\
(0.417)\end{array}$ & $\begin{array}{c}0.121 \\
(0.328)\end{array}$ & $\begin{array}{c}0.618 \\
(0.596)\end{array}$ & $\begin{array}{c}-1.240 \dagger \\
(0.704)\end{array}$ \\
\hline Observations & 753 & 753 & 753 & 753 & 753 \\
\hline $\mathrm{R}^{2}$ between & 0.695 & 0.708 & 0.768 & 0.699 & 0.785 \\
\hline $\mathrm{R}^{2}$ within & 0.780 & 0.782 & 0.781 & 0.790 & 0.791 \\
\hline Number of countries & 34 & 34 & 34 & 34 & 34 \\
\hline Year fixed effects & yes & yes & yes & yes & yes \\
\hline
\end{tabular}

Within-between regression of environmental policy stringency on different country features with year fixed effects in the OECD and BRIICS. Both within- and between-parts of the equation include controls for the level of electoral democracy, GDP per capita (natural log), trade openness, time in the EU, and corruption. Robust standard errors in parentheses, ${ }^{* * *} \mathrm{p}<0.001, * * \mathrm{p}<0.01, * \mathrm{p}<0.05, \dagger \mathrm{p}<0.1$. All independent variables are lagged 1 year. 
Table E.3. The relationship between thin liberal, social-liberal and deliberative features and environmental efforts in developing countries

\begin{tabular}{|c|c|c|c|c|c|}
\hline DV: Environmental efforts & Model 1 & Model 2 & Model 3 & Model 4 & Model 5 \\
\hline Between part: & & & & & \\
\hline Thin liberal features & & $\begin{array}{c}0.133 \\
(0.171)\end{array}$ & & & $\begin{array}{c}0.129 \\
(0.158)\end{array}$ \\
\hline Social-liberal features & & & $\begin{array}{l}0.323 \dagger \\
(0.168)\end{array}$ & & $\begin{array}{l}0.339 * \\
(0.163)\end{array}$ \\
\hline Deliberative features & & & & $\begin{array}{l}-0.150 \\
(0.240)\end{array}$ & $\begin{array}{l}-0.195 \\
(0.244)\end{array}$ \\
\hline Electoral democracy & $\begin{array}{c}2.449 * * * \\
(0.407)\end{array}$ & $\begin{array}{c}2.350^{* * *} \\
(0.454)\end{array}$ & $\begin{array}{c}2.495^{* * *} \\
(0.397)\end{array}$ & $\begin{array}{c}2.853^{* * *} \\
(0.772)\end{array}$ & $\begin{array}{c}2.925^{* * *} \\
(0.828)\end{array}$ \\
\hline GDP per capita (ln) & $\begin{array}{c}0.295^{* *} \\
(0.095)\end{array}$ & $\begin{array}{l}0.267^{*} \\
(0.106)\end{array}$ & $\begin{array}{c}0.209 * \\
(0.104)\end{array}$ & $\begin{array}{c}0.282^{* *} \\
(0.101)\end{array}$ & $\begin{array}{c}0.163 \\
(0.119)\end{array}$ \\
\hline Trade openness & $\begin{array}{c}0.494 * * * \\
(0.117)\end{array}$ & $\begin{array}{c}0.451 * * * \\
(0.133)\end{array}$ & $\begin{array}{c}0.406^{* *} \\
(0.128)\end{array}$ & $\begin{array}{c}0.505^{* * *} \\
(0.119)\end{array}$ & $\begin{array}{c}0.375^{* *} \\
(0.142)\end{array}$ \\
\hline Time in the EU & $\begin{array}{c}0.170^{* * *} \\
(0.045)\end{array}$ & $\begin{array}{c}0.171 * * * \\
(0.045)\end{array}$ & $\begin{array}{c}0.156^{* * *} \\
(0.043)\end{array}$ & $\begin{array}{c}0.160^{* * *} \\
(0.046)\end{array}$ & $\begin{array}{c}0.142^{* *} \\
(0.045)\end{array}$ \\
\hline Corruption & $\begin{array}{c}-1.955^{* * *} \\
(0.472)\end{array}$ & $\begin{array}{c}-1.966^{* * *} \\
(0.474)\end{array}$ & $\begin{array}{c}-1.544^{* *} \\
(0.473)\end{array}$ & $\begin{array}{c}-2.031 * * * \\
(0.496)\end{array}$ & $\begin{array}{c}-1.634^{* * *} \\
(0.494)\end{array}$ \\
\hline Within part: & & & & & \\
\hline Thin liberal features & & $\begin{array}{c}0.116 \\
(0.162)\end{array}$ & & & $\begin{array}{c}0.103 \\
(0.161)\end{array}$ \\
\hline Social-liberal features & & & $\begin{array}{c}0.325 \\
(0.277)\end{array}$ & & $\begin{array}{c}0.365 \\
(0.298)\end{array}$ \\
\hline Deliberative features & & & & $\begin{array}{l}-0.084 \\
(0.133)\end{array}$ & $\begin{array}{l}-0.120 \\
(0.138)\end{array}$ \\
\hline Electoral democracy & $\begin{array}{l}0.999 \dagger \\
(0.592)\end{array}$ & $\begin{array}{l}0.978 \dagger \\
(0.590)\end{array}$ & $\begin{array}{l}0.995 \dagger \\
(0.585)\end{array}$ & $\begin{array}{l}1.179 \dagger \\
(0.697)\end{array}$ & $\begin{array}{l}1.230 \dagger \\
(0.690)\end{array}$ \\
\hline GDP per capita (ln) & $\begin{array}{c}0.626 \\
(0.452)\end{array}$ & $\begin{array}{c}0.569 \\
(0.461)\end{array}$ & $\begin{array}{c}0.588 \\
(0.452)\end{array}$ & $\begin{array}{c}0.622 \\
(0.452)\end{array}$ & $\begin{array}{c}0.529 \\
(0.460)\end{array}$ \\
\hline Trade openness & $\begin{array}{c}0.146 \\
(0.101)\end{array}$ & $\begin{array}{c}0.138 \\
(0.101)\end{array}$ & $\begin{array}{c}0.152 \\
(0.098)\end{array}$ & $\begin{array}{c}0.152 \\
(0.105)\end{array}$ & $\begin{array}{c}0.154 \\
(0.103)\end{array}$ \\
\hline Time in the EU & $\begin{array}{l}-0.017 \\
(0.038)\end{array}$ & $\begin{array}{l}-0.016 \\
(0.038)\end{array}$ & $\begin{array}{l}-0.011 \\
(0.039)\end{array}$ & $\begin{array}{l}-0.016 \\
(0.038)\end{array}$ & $\begin{array}{l}-0.009 \\
(0.039)\end{array}$ \\
\hline Corruption & $\begin{array}{c}-1.161 \dagger \\
(0.697)\end{array}$ & $\begin{array}{c}-1.151 \dagger \\
(0.697)\end{array}$ & $\begin{array}{l}-1.044 \\
(0.678)\end{array}$ & $\begin{array}{c}-1.343 \dagger \\
(0.740)\end{array}$ & $\begin{array}{c}-1.279+ \\
(0.706)\end{array}$ \\
\hline Constant & $\begin{array}{c}2.311^{* *} \\
(0.715)\end{array}$ & $\begin{array}{c}2.153^{* *} \\
(0.687)\end{array}$ & $\begin{array}{l}1.616^{*} \\
(0.739)\end{array}$ & $\begin{array}{c}2.576^{* *} \\
(0.864)\end{array}$ & $\begin{array}{l}1.772^{*} \\
(0.875)\end{array}$ \\
\hline Observations & 718 & 718 & 718 & 718 & 718 \\
\hline $\mathrm{R}^{2}$ between & 0.719 & 0.721 & 0.730 & 0.720 & 0.733 \\
\hline $\mathrm{R}^{2}$ within & 0.076 & 0.077 & 0.080 & 0.077 & 0.082 \\
\hline Number of countries & 115 & 115 & 115 & 115 & 115 \\
\hline Year fixed effects & yes & yes & yes & yes & yes \\
\hline
\end{tabular}

Within-between regression of 'environmental efforts' in the developing world on different country features, with year fixed effects. Both within- and between-parts of the equation include controls for the level of electoral democracy, GDP per capita (natural log), trade openness, time in the EU, and corruption. Robust standard errors in parentheses, $* * * \mathrm{p}<0.001, * * \mathrm{p}<0.01, * \mathrm{p}<0.05, \dagger \mathrm{p}<0.1$. All independent variables are lagged 1 year. 


\section{Appendix F. Analysis with democracy features as operationalized by the Varieties of Democracy project}

We also run our analysis with democracy features as operationalized by the Varieties of Democracy project (Coppedge, Gerring, Knutsen, Lindberg, Teorell, Altman, Bernhard, Fish, Glynn, Hicken, Lührmann, Marquardt, McMann, Paxton, Pemstein, Seim, Sigman, Skaaning, Staton, Cornell, et al., 2020). The liberal component index contains indicators related to equality before law and individual liberties, including freedom of domestic movement, freedom from political killings, etc., judicial constraints on the executive, and legislative constraints on the executive. This operationalization of liberal features differs from the issues brought up in green political theory, but we are, nevertheless, interested in whether the features pertaining to the 'thick' understanding of liberal democracy correlate with environmental commitments as opposed to the 'thin' understanding tested in the main analysis. The egalitarian component index includes an index measuring equality in respect to the protection of civil liberties, an index measuring equality in access to power, and an index measuring equality in distribution of resources, which is the basis for our index of social-liberal features. The deliberative component index consists of indicators pertaining to reasoned justification, justifications in terms of a common good, respect of counterarguments, range of consultation, and engaged society. Our indictor of deliberative democracy includes the last three of the aforementioned indicators, and 'civil society consultations'.

The correlations between the V-Dem indicators and the indices used in our main analysis are presented in Table F.1. The table shows that our index of deliberative features has the highest correlation with the V-Dem's deliberative component (0.97). Our social-liberal features index and V-Dem's egalitarian component correlate at 0.89 , which is also very high. Thin liberal and VDem's liberal component have the lowest correlation coefficient (0.54), as expected, as they measure different phenomena. Despite the relatively high correlation between the social-liberal and deliberative features indices and the egalitarian and deliberative components from V-Dem respectively, our indices still correlate at a much lower degree than the V-Dem indicators, which makes their effects easier to disentangle in the statistical analysis. 
Table F.1. Correlation between V-Dem indicators and our indices measuring thin liberal, social-liberal, and deliberative features

\begin{tabular}{|c|c|c|c|c|c|c|}
\hline & $\begin{array}{l}\text { Thin } \\
\text { Liberal }\end{array}$ & $\begin{array}{l}\text { Social } \\
\text { Liberal }\end{array}$ & Deliberative & $\begin{array}{l}\text { Liberal } \\
\text { (V-Dem) }\end{array}$ & $\begin{array}{l}\text { Egalitarian } \\
\text { (V-Dem) }\end{array}$ & $\begin{array}{l}\text { Deliberative } \\
\text { (V-Dem) }\end{array}$ \\
\hline Thin Liberal & 1.00 & & & & & \\
\hline Social Liberal & 0.55 & 1.00 & & & & \\
\hline Deliberative & 0.52 & 0.58 & 1.00 & & & \\
\hline Liberal (V-Dem) & 0.54 & 0.68 & 0.87 & 1.00 & & \\
\hline Egalitarian (V-Dem) & 0.49 & 0.89 & 0.72 & 0.81 & 1.00 & \\
\hline Deliberative (V-Dem) & 0.49 & 0.58 & 0.97 & 0.86 & 0.72 & 1.00 \\
\hline
\end{tabular}


Table F.2. The relationship between liberal, egalitarian, and deliberative features (from V-Dem) and effectiveness of climate laws

\begin{tabular}{|c|c|c|c|c|c|c|}
\hline \multirow[b]{2}{*}{$\mathrm{DV}: \ln \left(\mathrm{CO}_{2} / \mathrm{GDP}\right)$} & \multicolumn{3}{|c|}{ Sample of democracies } & \multicolumn{3}{|c|}{ Full sample } \\
\hline & 1 & 2 & 3 & 4 & 5 & 6 \\
\hline \multirow[t]{2}{*}{ Liberal features } & 0.037 & & & 0.086 & & \\
\hline & $(0.122)$ & & & $(0.150)$ & & \\
\hline \multirow[t]{2}{*}{ Stock of laws*Liberal } & -0.027 & & & $-0.030 \dagger$ & & \\
\hline & $(0.020)$ & & & $(0.017)$ & & \\
\hline \multirow[t]{2}{*}{ Egalitarian features } & & 0.244 & & & -0.024 & \\
\hline & & $(0.202)$ & & & $(0.201)$ & \\
\hline \multirow[t]{2}{*}{ Stock of laws*Egalitarian } & & $-0.034 *$ & & & $-0.049 *$ & \\
\hline & & $(0.014)$ & & & $(0.020)$ & \\
\hline \multirow[t]{2}{*}{ Deliberative features } & & & -0.005 & & & 0.013 \\
\hline & & & $(0.094)$ & & & $(0.082)$ \\
\hline \multirow[t]{2}{*}{ Stock of laws*Deliberative } & & & 0.020 & & & -0.003 \\
\hline & & & $(0.027)$ & & & $(0.019)$ \\
\hline \multirow[t]{2}{*}{ Stock of mitigation laws } & 0.016 & $0.021 \dagger$ & -0.023 & 0.015 & $0.029 \dagger$ & -0.006 \\
\hline & $(0.018)$ & $(0.012)$ & $(0.024)$ & $(0.013)$ & $(0.015)$ & $(0.016)$ \\
\hline \multirow[t]{2}{*}{ Electoral democracy } & & & & -0.060 & -0.013 & -0.023 \\
\hline & & & & $(0.169)$ & $(0.112)$ & $(0.119)$ \\
\hline \multirow[t]{2}{*}{ Constant } & $-11.431 * * *$ & $-11.283^{* * *}$ & $-12.014 * * *$ & $-9.056^{*}$ & $-8.811 *$ & $-9.535^{* *}$ \\
\hline & $(3.350)$ & $(3.289)$ & $(3.257)$ & $(3.587)$ & $(3.567)$ & $(3.501)$ \\
\hline Observations & 1,480 & 1,480 & 1,480 & 2,074 & 2,074 & 2,074 \\
\hline $\mathrm{R}^{2}$ & 0.476 & 0.479 & 0.475 & 0.313 & 0.316 & 0.311 \\
\hline Number of countries & 94 & 94 & 94 & 126 & 126 & 126 \\
\hline Year fixed effects & yes & yes & yes & yes & yes & yes \\
\hline \multicolumn{7}{|c|}{$\begin{array}{l}\text { OLS regression of a natural logarithm of } \mathrm{CO}_{2} \text { emissions per } 2011 \text { PPP } \$ 1 \text { GDP on the interaction effect between the stock of } \\
\text { recent mitigation laws and different country features (as operationalized by V-Dem), with country and year fixed effects. } \\
\text { Models } 1-3 \text { are for the sample of democracies as categorized by Bjørnskov-Rode }(2020) \text {. Models } 4-6 \text { are for the full sample of } \\
\text { countries. All regressions control for the level of democracy, the GDP HP filter, squared term of GDP per capita (natural } \\
\text { log), the size of imports and services as a percentage of GDP, difference between the yearly average temperature and the long } \\
\text { term (1980-2015) average temperature, and federalism. Models } 4-6 \text { also include a control for the level of electoral democracy. } \\
\text { Robust standard errors in parentheses, }{ }^{* * *} \mathrm{p}<0.001,{ }^{*} \mathrm{p}<0.01,{ }^{*} \mathrm{p}<0.05, \dagger \mathrm{p}<0.1 \text {. All independent variables are lagged } 1 \text { year. }\end{array}$} \\
\hline
\end{tabular}


1) Conditional Marginal Effect of $N$ Laws

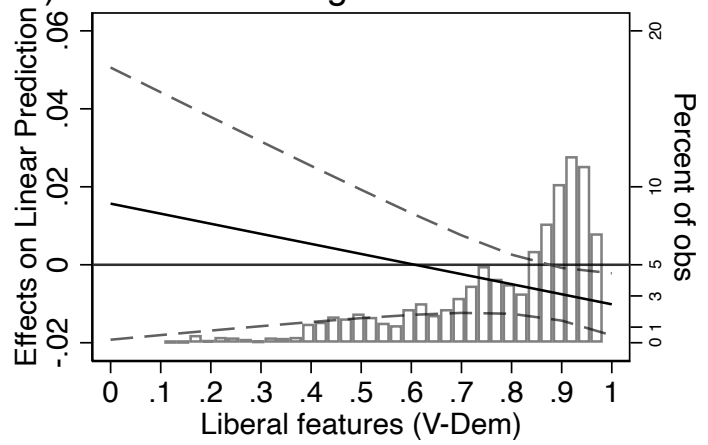

3) Conditional Marginal Effect of N Laws

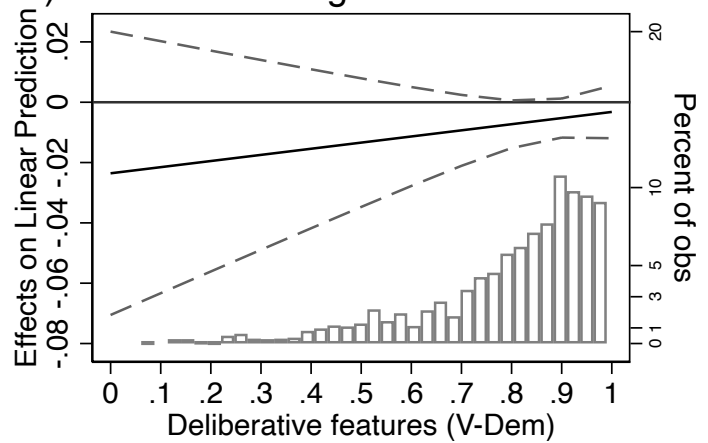

2) Conditional Marginal Effect of $N$ Laws

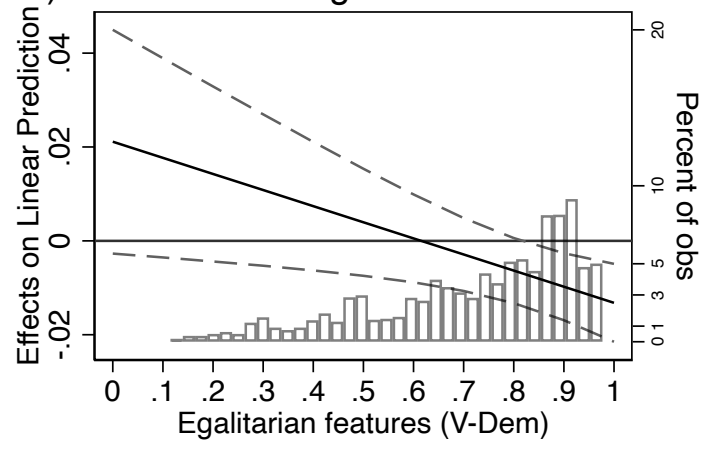

Figure F.1. Marginal effects of the stock of recent climate change mitigation laws on $\mathrm{CO}_{2}$ emissions conditional on the extent of liberal features (1), egalitarian features (2), and deliberative features (3) in democracies, with 95\% confidence intervals, Models 1-3 of Table F.2. 
4) Conditional Marginal Effect of N Laws

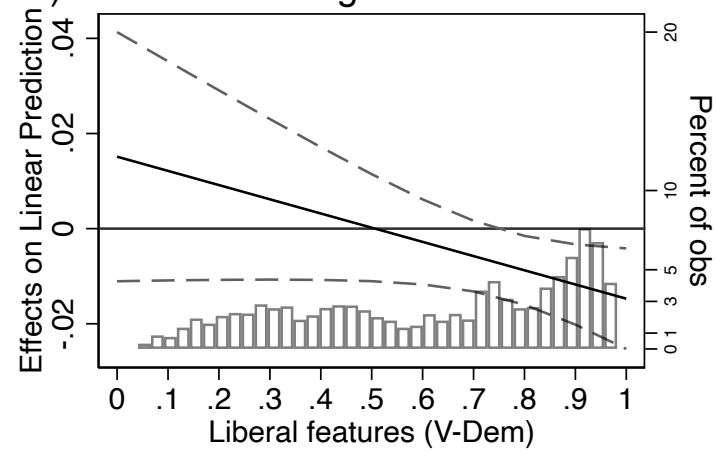

5) Conditional Marginal Effect of N Laws

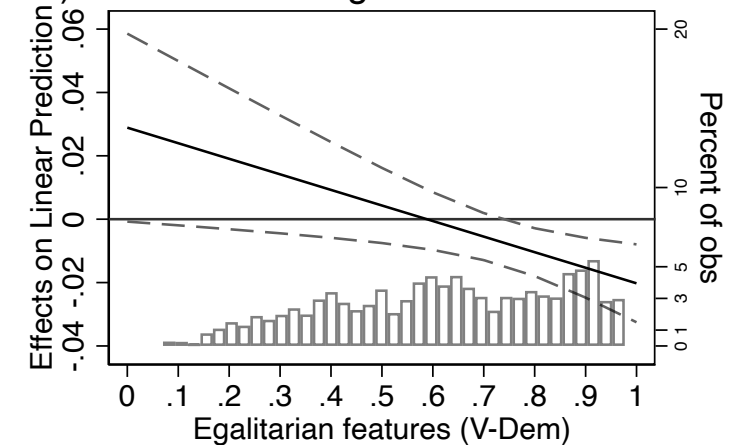

6) Conditional Marginal Effect of N Laws

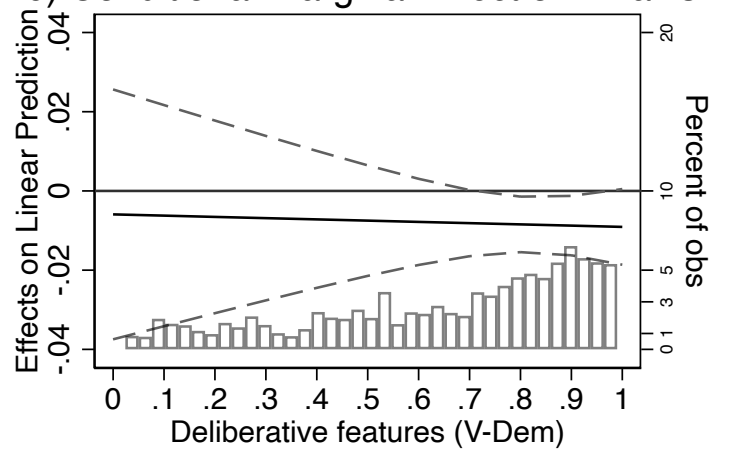

Figure F.2. Marginal effects of the stock of recent climate change mitigation laws on $\mathrm{CO}_{2}$ emissions conditional on the extent of liberal features (4), egalitarian features (5), and deliberative features (6) in the world countries, with $95 \%$ confidence intervals, Models 4-6 of Table F.2. 
Table F.2. The relationship between thin liberal, egalitarian, and deliberative features (from V-Dem) and environmental policy stringency in OECD and BRIICS

\begin{tabular}{|c|c|c|c|c|c|c|c|c|}
\hline \multirow[b]{2}{*}{ DV: EPS } & \multicolumn{4}{|c|}{ Sample of democracies } & \multicolumn{4}{|c|}{ Full sample } \\
\hline & 1 & 2 & 3 & 4 & 5 & 6 & 7 & 8 \\
\hline \multicolumn{9}{|l|}{$\underline{\text { Between }}$} \\
\hline \multirow[t]{2}{*}{ Liberal features } & -0.204 & & & $-3.098 *$ & -1.441 & & & 0.769 \\
\hline & $(1.841)$ & & & $(1.577)$ & $(3.189)$ & & & $(2.449)$ \\
\hline \multirow[t]{2}{*}{ Egalitarian features } & & $2.681 * * *$ & & $4.097 * * *$ & & $3.056^{* * *}$ & & $3.159 * * *$ \\
\hline & & $(0.735)$ & & $(0.891)$ & & $(0.687)$ & & $(0.834)$ \\
\hline \multirow[t]{2}{*}{ Deliberative features } & & & 0.564 & -0.396 & & & -0.153 & -0.041 \\
\hline & & & $(1.200)$ & $(1.076)$ & & & $(1.226)$ & $(0.981)$ \\
\hline \multirow[t]{2}{*}{ Electoral democracy } & & & & & 1.401 & $-1.143^{* *}$ & 0.220 & -1.872 \\
\hline & & & & & $(3.030)$ & $(0.436)$ & $(0.602)$ & $(2.354)$ \\
\hline \multirow[t]{2}{*}{ GDP per capita (ln) } & 0.004 & 0.001 & 0.002 & 0.002 & 0.004 & -0.001 & 0.004 & -0.001 \\
\hline & $(0.004)$ & $(0.005)$ & $(0.005)$ & $(0.005)$ & $(0.004)$ & $(0.004)$ & $(0.005)$ & $(0.005)$ \\
\hline \multirow[t]{2}{*}{ Trade openness } & 0.793 & -0.465 & 1.024 & -1.491 & 1.693 & -0.083 & 1.239 & -0.513 \\
\hline & $(2.619)$ & $(2.182)$ & $(2.055)$ & $(2.304)$ & $(2.659)$ & $(2.207)$ & $(2.315)$ & $(2.443)$ \\
\hline \multirow{2}{*}{ Time in the EU } & $0.006 \dagger$ & 0.004 & 0.005 & 0.004 & $0.006 \dagger$ & 0.004 & $0.006 \dagger$ & 0.004 \\
\hline & $(0.003)$ & $(0.003)$ & $(0.003)$ & $(0.003)$ & $(0.003)$ & $(0.003)$ & $(0.004)$ & $(0.003)$ \\
\hline \multirow[t]{2}{*}{ Corruption } & $-1.667 \dagger$ & $-0.834 *$ & $-1.540 * * *$ & $-1.253^{* *}$ & $-1.821 * * *$ & $-1.174 * * *$ & $-1.629 * * *$ & $-1.044 *$ \\
\hline & $(0.978)$ & $(0.335)$ & $(0.397)$ & $(0.479)$ & $(0.460)$ & $(0.306)$ & $(0.426)$ & $(0.433)$ \\
\hline \multicolumn{9}{|l|}{$\underline{\text { Within }}$} \\
\hline \multirow{2}{*}{ Liberal features } & $-3.144 * *$ & & & $-2.201 \dagger$ & -2.218 & & & -1.016 \\
\hline & $(1.212)$ & & & $(1.145)$ & $(1.738)$ & & & $(1.673)$ \\
\hline \multirow[t]{2}{*}{ Egalitarian features } & & -1.498 & & 0.304 & & -1.312 & & -1.582 \\
\hline & & $(1.600)$ & & $(1.523)$ & & (1.044) & & $(1.026)$ \\
\hline \multirow[t]{2}{*}{ Deliberative features } & & & $-2.333 *$ & -1.514 & & & $-1.567 \dagger$ & $-1.371 \dagger$ \\
\hline & & & $(1.085)$ & $(1.126)$ & & & $(0.921)$ & $(0.810)$ \\
\hline \multirow[t]{2}{*}{ Electoral democracy } & & & & & 1.078 & -0.041 & 0.170 & 1.870 \\
\hline & & & & & $(1.507)$ & $(1.158)$ & $(0.867)$ & $(1.582)$ \\
\hline \multirow[t]{2}{*}{ GDP per capita (ln) } & 0.019 & $0.028 \dagger$ & 0.022 & 0.018 & $0.034 *$ & $0.038^{*}$ & $0.033^{*}$ & $0.033^{*}$ \\
\hline & $(0.015)$ & $(0.016)$ & $(0.015)$ & $(0.014)$ & $(0.016)$ & $(0.016)$ & $(0.016)$ & $(0.017)$ \\
\hline \multirow[t]{2}{*}{ Trade openness } & -1.211 & 0.588 & -1.331 & -2.007 & 1.699 & 2.118 & 1.315 & 1.113 \\
\hline & $(5.440)$ & $(5.078)$ & $(5.080)$ & $(5.356)$ & $(5.571)$ & (5.223) & $(5.359)$ & $(5.203)$ \\
\hline \multirow[t]{2}{*}{ Time in the EU } & 0.004 & 0.007 & 0.009 & 0.007 & 0.014 & 0.015 & 0.016 & 0.015 \\
\hline & $(0.013)$ & $(0.014)$ & $(0.013)$ & $(0.013)$ & $(0.014)$ & $(0.014)$ & $(0.013)$ & $(0.013)$ \\
\hline \multirow[t]{2}{*}{ Corruption } & $-3.112^{* *}$ & $-2.124 \dagger$ & $-3.648^{* *}$ & $-3.924 * * *$ & $-2.275 \dagger$ & -1.646 & $-2.847^{*}$ & $-2.950 *$ \\
\hline & (1.113) & $(1.200)$ & $(1.126)$ & (1.181) & $(1.375)$ & $(1.517)$ & $(1.316)$ & $(1.356)$ \\
\hline \multirow[t]{2}{*}{ Constant } & 1.091 & $-1.167 \dagger$ & 0.549 & 0.752 & $1.221 *$ & -0.255 & 1.090 & -0.437 \\
\hline & $(1.744)$ & $(0.612)$ & (1.066) & $(0.918)$ & $(0.528)$ & $(0.351)$ & $(0.827)$ & $(0.808)$ \\
\hline Observations & 672 & 672 & 672 & 672 & 753 & 753 & 753 & 753 \\
\hline $\mathrm{R}^{2}$ between & 0.816 & 0.709 & 0.614 & 0.737 & 0.697 & 0.786 & 0.696 & 0.793 \\
\hline $\mathrm{R}^{2}$ within & 0.596 & 0.807 & 0.816 & 0.819 & 0.786 & 0.783 & 0.787 & 0.792 \\
\hline Number of countreis & 31 & 31 & 31 & 31 & 34 & 34 & 34 & 34 \\
\hline Year fixed effects & yes & yes & yes & yes & yes & yes & yes & yes \\
\hline \multicolumn{9}{|c|}{$\begin{array}{l}\text { Within-between regression of environmental policy stringency in the OECD and BRIICS on different country features (as } \\
\text { operationalized by V-Dem), with year fixed effects. Models } 1-4 \text { are for the sample of democracies as categorized by Bjørnskov-Rode } \\
\text { (2020). Models } 5-8 \text { are for the full sample of countries. Both within- and between-parts of the equation include controls for GDP per } \\
\text { capita (natural log), trade openness, time in the EU, and corruption. In Models } 5-8 \text { both within- and between-parts also include a } \\
\text { control for the level of electoral democracy. Robust standard errors in parentheses, }{ }^{* * *} \mathrm{p}<0.001,{ }^{* *} \mathrm{p}<0.01,{ }^{*} \mathrm{p}<0.05, \dagger \mathrm{p}<0.1 \text {. All } \\
\text { independent variables are lagged } 1 \text { year. }\end{array}$} \\
\hline
\end{tabular}



Table F.3. The relationship between thin liberal, egalitarian, and deliberative features
(from V-Dem) and environmental efforts in developing countries

\begin{tabular}{|c|c|c|c|c|c|c|c|c|}
\hline \multirow[b]{2}{*}{ DV: Envir. efforts } & \multicolumn{4}{|c|}{ Sample of democracies } & \multicolumn{4}{|c|}{ Full sample } \\
\hline & 1 & 2 & 3 & 4 & 5 & 6 & 7 & 8 \\
\hline \multicolumn{9}{|l|}{ Between } \\
\hline \multirow[t]{2}{*}{ Liberal features } & 0.735 & & & 1.082 & 0.463 & & & 0.846 \\
\hline & $(1.013)$ & & & $(1.146)$ & $(0.977)$ & & & $(0.956)$ \\
\hline \multirow[t]{2}{*}{ Egalitarian features } & & 0.629 & & 0.451 & & $1.269 \dagger$ & & $1.336 \dagger$ \\
\hline & & $(0.964)$ & & $(1.068)$ & & $(0.678)$ & & $(0.682)$ \\
\hline \multirow[t]{2}{*}{ Deliberative features } & & & 0.085 & -0.671 & & & -0.546 & -1.183 \\
\hline & & & $(1.082)$ & $(1.128)$ & & & $(0.813)$ & $(0.848)$ \\
\hline \multirow[t]{2}{*}{ Electoral democracy } & & & & & $2.078^{*}$ & $2.028^{* * *}$ & $2.857 * * *$ & $2.220^{*}$ \\
\hline & & & & & $(0.910)$ & $(0.462)$ & $(0.733)$ & $(0.980)$ \\
\hline \multirow[t]{2}{*}{ GDP per capita (ln) } & $0.488^{* *}$ & $0.487 * * *$ & $0.497 * *$ & $0.472 * *$ & $0.299 * *$ & $0.292^{* *}$ & $0.284 * *$ & $0.277 * *$ \\
\hline & $(0.149)$ & $(0.147)$ & $(0.152)$ & $(0.152)$ & $(0.099)$ & $(0.097)$ & $(0.099)$ & $(0.101)$ \\
\hline \multirow[t]{2}{*}{ Trade openness } & $0.476 \dagger$ & $0.413 \dagger$ & $0.452 \dagger$ & $0.456 \dagger$ & $0.482^{* * *}$ & $0.441^{* * *}$ & $0.509 * * *$ & $0.452^{* * *}$ \\
\hline & $(0.243)$ & $(0.246)$ & $(0.236)$ & $(0.264)$ & $(0.117)$ & $(0.120)$ & $(0.119)$ & $(0.125)$ \\
\hline \multirow[t]{2}{*}{ Time in the EU } & $0.183^{* * *}$ & $0.184 * * *$ & $0.191 * * *$ & $0.171^{* *}$ & $0.173^{* * *}$ & $0.161 * * *$ & $0.159 * * *$ & $0.140 * *$ \\
\hline & $(0.053)$ & $(0.052)$ & $(0.051)$ & $(0.052)$ & $(0.044)$ & $(0.043)$ & $(0.046)$ & $(0.045)$ \\
\hline \multirow[t]{2}{*}{ Corruption } & $-1.655^{*}$ & $-1.768^{*}$ & $-1.954 * *$ & $-1.578^{*}$ & $-1.846^{* * *}$ & $-1.588^{* *}$ & $-2.053 * * *$ & $-1.580^{* *}$ \\
\hline & $(0.684)$ & $(0.824)$ & $(0.707)$ & $(0.804)$ & $(0.534)$ & $(0.511)$ & $(0.503)$ & $(0.544)$ \\
\hline \multicolumn{9}{|l|}{$\underline{\text { Within }}$} \\
\hline \multirow[t]{2}{*}{ Liberal features } & -0.048 & & & -0.134 & $-1.193 \dagger$ & & & $-1.235 \dagger$ \\
\hline & $(0.745)$ & & & $(0.746)$ & $(0.681)$ & & & $(0.652)$ \\
\hline \multirow[t]{2}{*}{ Egalitarian features } & & $1.635 \dagger$ & & $1.771 \dagger$ & & 0.926 & & 1.374 \\
\hline & & $(0.900)$ & & $(0.909)$ & & $(0.909)$ & & $(0.936)$ \\
\hline \multirow[t]{2}{*}{ Deliberative features } & & & -0.153 & -0.225 & & & -0.442 & -0.360 \\
\hline & & & $(0.489)$ & $(0.504)$ & & & $(0.450)$ & $(0.420)$ \\
\hline \multirow[t]{2}{*}{ Electoral democracy } & & & & & $1.650^{*}$ & 0.919 & $1.264 \dagger$ & $1.768^{*}$ \\
\hline & & & & & $(0.737)$ & $(0.589)$ & $(0.708)$ & $(0.791)$ \\
\hline \multirow[t]{2}{*}{ GDP per capita (ln) } & 0.113 & 0.066 & 0.107 & 0.081 & 0.589 & 0.617 & 0.627 & 0.583 \\
\hline & $(0.663)$ & $(0.654)$ & $(0.656)$ & $(0.652)$ & $(0.447)$ & $(0.452)$ & $(0.450)$ & $(0.445)$ \\
\hline \multirow[t]{2}{*}{ Trade openness } & -0.277 & -0.225 & -0.276 & -0.242 & 0.143 & 0.150 & 0.158 & 0.159 \\
\hline & $(0.277)$ & $(0.278)$ & $(0.271)$ & $(0.283)$ & $(0.105)$ & $(0.099)$ & $(0.106)$ & $(0.107)$ \\
\hline \multirow[t]{2}{*}{ Time in the EU } & -0.007 & -0.009 & -0.007 & -0.008 & -0.017 & -0.018 & -0.016 & -0.016 \\
\hline & $(0.042)$ & $(0.041)$ & $(0.042)$ & $(0.042)$ & $(0.038)$ & $(0.038)$ & $(0.038)$ & $(0.038)$ \\
\hline \multirow[t]{2}{*}{ Corruption } & -1.276 & -1.029 & -1.333 & -1.242 & $-1.618^{*}$ & -1.021 & $-1.413 \dagger$ & $-1.633^{*}$ \\
\hline & $(1.018)$ & $(0.967)$ & (1.033) & $(1.064)$ & $(0.759)$ & $(0.729)$ & $(0.756)$ & $(0.806)$ \\
\hline \multirow[t]{2}{*}{ Constant } & $2.948 \dagger$ & $3.381 * *$ & $3.649 *$ & $2.986 \dagger$ & $2.201 * *$ & $1.794^{*}$ & $2.478^{* *}$ & $1.905^{*}$ \\
\hline & (1.604) & $(1.226)$ & $(1.594)$ & $(1.785)$ & $(0.758)$ & $(0.744)$ & $(0.791)$ & $(0.813)$ \\
\hline Observations & 420 & 420 & 420 & 420 & 718 & 718 & 718 & 718 \\
\hline $\mathrm{R}^{2}$ between & 0.697 & 0.695 & 0.695 & 0.698 & 0.720 & 0.729 & 0.720 & 0.734 \\
\hline $\mathrm{R}^{2}$ within & 0.073 & 0.083 & 0.079 & 0.085 & 0.083 & 0.078 & 0.079 & 0.089 \\
\hline Number of countries & 70 & 70 & 70 & 70 & 115 & 115 & 115 & 115 \\
\hline Year fixed effects & yes & yes & yes & yes & yes & yes & yes & yes \\
\hline $\begin{array}{l}\text { Within-between regres } \\
\text { Dem), with year fixed } \\
\text { for the full sample of } \\
\text { trade openness, time } \\
\text { standard errors in pare }\end{array}$ & $\begin{array}{l}\text { of 'enviro } \\
\text { ts. Model }\end{array}$ & ntal effort & the deve & $\begin{array}{l}\text { ing worl } \\
\text { cracies a }\end{array}$ & different & $\begin{array}{l}\text { untry featu } \\
\text { Bjørnskov }\end{array}$ & (as operat & $\begin{array}{l}\text { nalized by } \\
\text { odels } 5-8 \text { a } \\
\text { (natural lo }\end{array}$ \\
\hline
\end{tabular}

